\title{
THE
}

$10-3-2018$

\section{Trichophycins B-F, Chlorovinylidene-Containing Polyketides Isolated from a Cyanobacterial Bloom}

\author{
Matthew Bertin \\ University of Rhode Island, mbertin@uri.edu \\ Josep Sauri \\ Yizhou Liu \\ Christopher W. Via \\ Alexandre F. Roduit
}

See next page for additional authors

Follow this and additional works at: https://digitalcommons.uri.edu/bps_facpubs

\section{The University of Rhode Island Faculty have made this article openly available. Please let us know how Open Access to this research benefits you.}

This is a pre-publication author manuscript of the final, published article.

Terms of Use

This article is made available under the terms and conditions applicable towards Open Access Policy Articles, as set forth in our Terms of Use.

\section{Citation/Publisher Attribution}

Matthew J. Bertin, Josep Saurí, Yizhou Liu, Christopher W. Via, Alexandre F. Roduit, and R. Thomas Williamson. The Journal of Organic Chemistry 201883 (21), 13256-13266. DOI: 10.1021/acs.joc.8b02070

This Article is brought to you for free and open access by the Biomedical and Pharmaceutical Sciences at DigitalCommons@URI. It has been accepted for inclusion in Biomedical and Pharmaceutical Sciences Faculty Publications by an authorized administrator of DigitalCommons@URI. For more information, please contact digitalcommons-group@uri.edu. 


\section{Authors}

Matthew Bertin, Josep Sauri, Yizhou Liu, Christopher W. Via, Alexandre F. Roduit, and R. Thomas Williamson 
This document is the Accepted Manuscript version of a Published Work that appeared in final form in The Journal of Organic Chemistry, copyright (C) American Chemical Society after peer review and technical editing by the publisher. To access the final edited and published work see https://pubs.acs.org/articlesonrequest/AOR-vRKxX4NKsdfyWkM93BEb

\section{Trichophycins B-F, chlorovinylidene-containing polyketides isolated from a cyanobacterial bloom}

Matthew J. Bertin, ${ }^{\dagger}, *$ Josep Saurí, ${ }^{\star}$ Yizhou Liu, ${ }^{\S}$ Christopher W. Via ${ }^{\dagger}$ Alexandre F. Roduit, ${ }^{\dagger}$ R. Thomas Williamson,

${ }^{\dagger}$ Department of Biomedical and Pharmaceutical Sciences, College of Pharmacy, University of Rhode Island, Kingston, RI 02881, United States

${ }^{*}$ Structure Elucidation Group, Analytical Research \& Development, Merck and Co. Inc., Boston, MA 02115, United States

${ }^{\S}$ Structure Elucidation Group, Analytical Research \& Development, Merck and Co. Inc., Rahway, NJ 07065, United States

*Corresponding author. Tel: (401) 874-5016; fax: (401) 874-2181

Email address: mbertin@uri.edu

Author Mailing Address:

University of Rhode Island

7 Greenhouse Road, Avedisian Hall, Room 495M

Kingston, RI 02881 


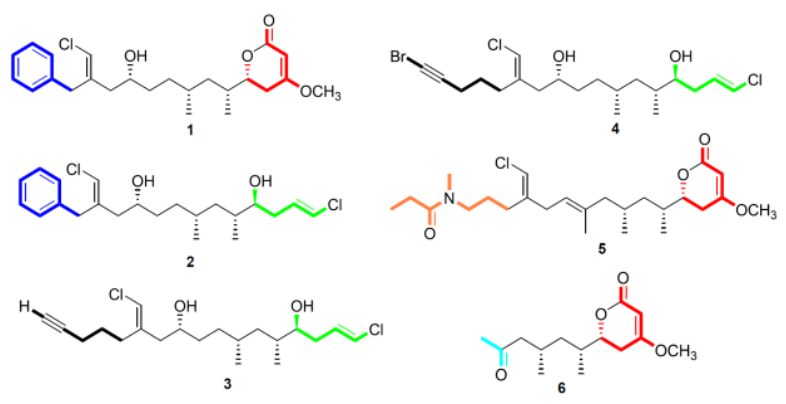

\section{ABSTRACT}

NMR-guided isolation (based on $1 \mathrm{D}{ }^{1} \mathrm{H}$ and ${ }^{13} \mathrm{C}$ NMR resonances consistent with a chlorovinylidene moiety) resulted in the characterization of five new highly functionalized polyketides, trichophycins B-F (1-5) and one non-chlorinated metabolite tricholactone (6) from a collection of Trichodesmium bloom material from the Gulf of Mexico. The planar structures of 1-6 were determined using 1D and 2D NMR spectroscopy, mass spectrometry and complementary spectroscopic procedures. Absolute configuration analysis of $\mathbf{1}$ and $\mathbf{2}$ were carried out by ${ }^{1} \mathrm{H}$ NMR analysis of diastereomeric Mosher esters in addition to ECD spectroscopy, $J$-based configuration analysis and DFT calculations. The absolute configurations of 3-6 were proposed based on comparative analysis of ${ }^{13} \mathrm{C}$ NMR chemical shifts, relative configurations, and optical rotation values to compounds $\mathbf{1}$ and $\mathbf{2}$. Compounds $\mathbf{1 - 5}$ represent new additions to the trichophycin family and are hallmarked by a chlorovinylidene moiety. These new trichophycins and tricholactone (1-6) feature intriguing variations with respect to putative biosynthetic starting units, halogenation, and terminations and trichophycin E (4) features a rare alkynyl bromide functionality. The phenyl-containing trichophycins showed low cytotoxicity to neuro-2A cells, while the alkyne-containing trichophycins showed no toxicity. 


\section{INTRODUCTION}

Filamentous marine cyanobacteria continue to be an important source for the isolation of chemically diverse and biologically active secondary metabolites. ${ }^{1-4}$ Many of these molecules recognizably derive from polyketide synthase (PKS) biosynthetic pathways, non-ribosomal peptide synthetase (NRPS) pathways, or mixed PKS-NRPS pathways. ${ }^{5}$ Variations in the biosynthetic architecture that create these metabolites has led to remarkable chemical diversity and the evaluation of these cyanobacterial secondary metabolites in a broad range of biological assays has led to the identification of therapeutically-relevant biological activities including cytotoxicity, ${ }^{6,7}$ neuromodulation, ${ }^{8,9}$ anti-parasitism,,${ }^{10}$ and anti-inflammation. ${ }^{11}$ The availability of chloride, bromide and iodide in seawater and the action of halogenase enzymes in cyanobacterial biosynthetic pathways allows halide incorporation into marine natural products. ${ }^{12}$ Prior examples isolated from cyanobacteria include the lipoamides jamaicamide $\mathrm{A},{ }^{13}$ several vinyl chloridecontaining malyngamides, ${ }^{14,15}$ and the polyketide kimbelactone. ${ }^{16}$

The vinyl chloride containing trichotoxins ${ }^{17}$ and the cytotoxic linear polyketide trichophycin $\mathrm{A}^{18}$ have been isolated from an environmental bloom of Trichodesmium by our laboratory. In an effort to gain greater insight into the secondary metabolite profile of these ecologically relevant bloom events and the chemical speciation of the chlorovinylidene-containing trichophycins, we examined lipophilic extracts and fractions of bloom material remaining in our laboratory from an event in the Gulf of Mexico in 2014. Six structurally similar compounds, five of which were halogenated and all presumably derived from a PKS system, were isolated and evaluated for cytotoxicity against the neuro-2A mouse neuroblastoma cell line. These new trichophycins and tricholactone (1-6) feature intriguing variations with respect to putative biosynthetic starting units, halogenation and terminations with trichophycin B (1), trichophycin F (5) and tricholactone (6) terminating in 
a functionalized lactone moiety and trichophycins C-E (2-4) featuring a terminal vinyl chloride group (Figure 1). A structure-activity relationship (SAR) suggests that phenyl-containing trichophycins and those with greater polyol character possess more significant cytotoxicity.

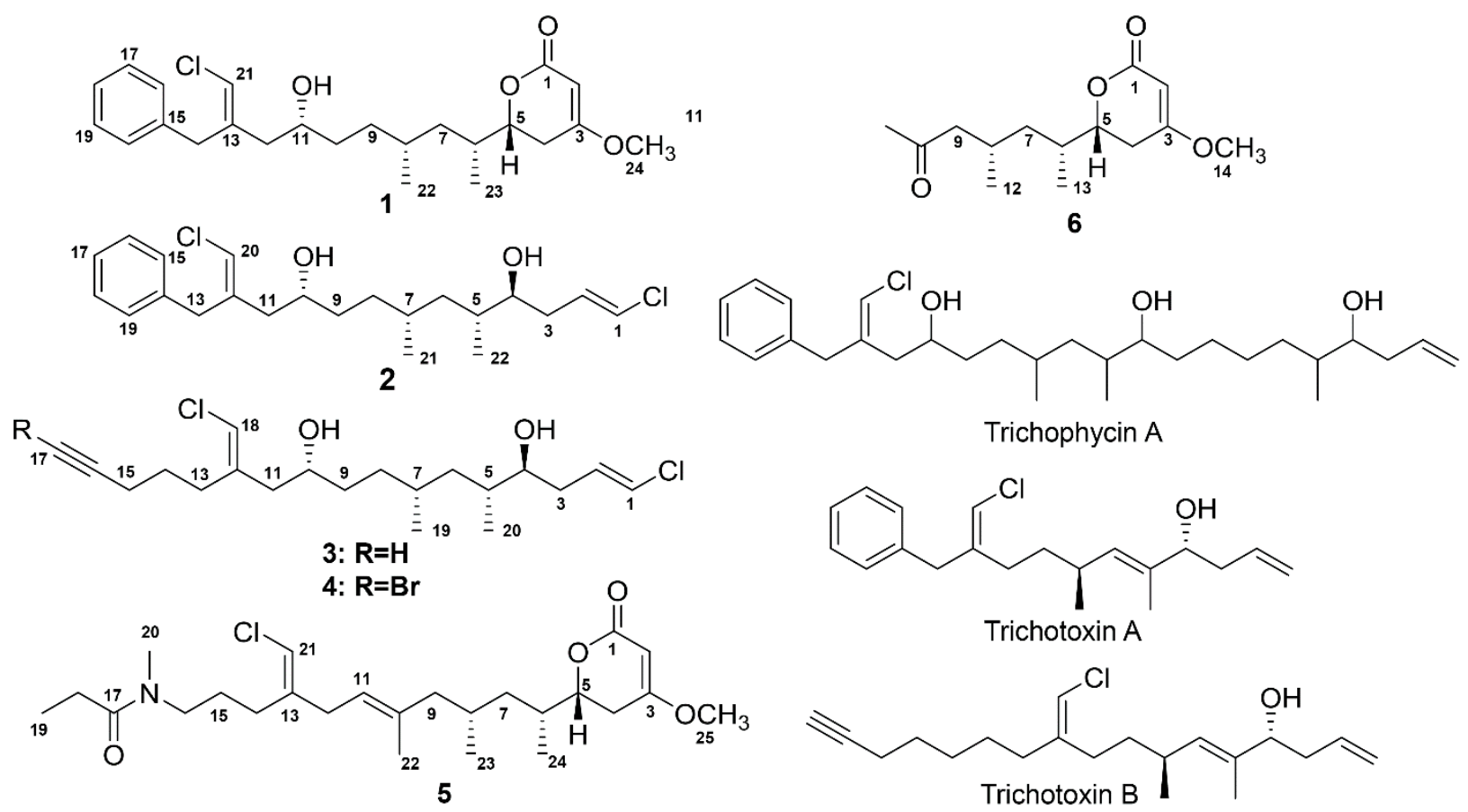

Figure 1. Structures of compound 1-6 and the previously reported trichophycin $\mathrm{A}^{18}$ and trichotoxins A and B. ${ }^{17}$

\section{RESULTS AND DISCUSSION}

Characterization of 1-6. The extraction of Trichodesmium bloom material and fractionation of the crude extract guided by evaluation of $1 \mathrm{D}{ }^{1} \mathrm{H}$ NMR and ${ }^{13} \mathrm{C}$ NMR spectra led to the isolation of six structurally similar compounds (1-6). Trichophycin B (1) was isolated as an optically active pale yellow oil. HRESIMS analysis of 1 gave an $[\mathrm{M}+\mathrm{H}]^{+}$of $m / z$ 421.2153, suggesting a molecular formula of $\mathrm{C}_{24} \mathrm{H}_{33} \mathrm{ClO}_{4}$ and a requirement of 8 degrees of unsaturation. Examination and comparison of the ${ }^{13} \mathrm{C}$ NMR, and 2D NMR spectra aided by a multiplicityedited HSQC experiment showed the presence of 3 methyls, one of which was a methoxy group, 
6 methylenes, 11 methines and 2 moderately deshielded olefinic carbons $\left(\delta_{\mathrm{C}} 138.7\right.$ and 138.2), 1 deshielded olefinic carbon $\left(\left(\delta_{\mathrm{C}} 173.3\right)\right.$, and 1 carbonyl carbon with a chemical shift consistent with that of an ester group $\left(\delta_{\mathrm{C}} 167.7\right)$ (Table 1). The ${ }^{1} \mathrm{H}$ and ${ }^{13} \mathrm{C}$ NMR spectra of 1 showed the characteristic signals of an aromatic ring for positions 15-20. Deshielded diastereotopic methylene protons $\left(\mathrm{H}_{2}-14, \delta_{\mathrm{H}} 3.75,3.51\right)$ showed $\mathrm{HMBC}$ correlations to the quaternary carbon of the aromatic ring $\left(\mathrm{C}-15, \delta_{\mathrm{C}} 138.2\right)$ and to a moderately polarized olefin comprised of a quaternary carbon $\left(\mathrm{C}-13, \delta_{\mathrm{C}} 138.7\right)$ and a carbon $\left(\mathrm{C}-21, \delta_{\mathrm{C}} 115.4\right)$ bearing a singlet methine proton at $\delta_{\mathrm{H}} 6.07$. These chemical shifts were consistent with the presence of a vinyl chloride functionality, and considering the aromatic moiety, accounted for 5 of the 8 required degrees of unsaturation. NOE correlations between $\mathrm{H}-21\left(\delta_{\mathrm{H}} 6.07\right)$ and $\mathrm{H}_{2}-12\left(\delta_{\mathrm{H}} 2.17,2.07\right)$ and $\mathrm{H}-11\left(\delta_{\mathrm{H}}\right.$ 3.60) supported a $E$ geometry of the chlorovinylidene group. Moderately deshielded methylene protons $\mathrm{H}_{2}-12\left(\mathrm{H}-2 \mathrm{a}, \delta_{\mathrm{H}} 2.17 ; \mathrm{H}-2 \mathrm{~b}, \delta_{\mathrm{H}} 2.07\right)$ showed $\mathrm{HMBC}$ correlations to the vinyl chloridecontaining olefin, and examination of the ${ }^{1} \mathrm{H}-{ }^{1} \mathrm{H}$ COSY spectrum showed an extended spin system from $\mathrm{H}_{2}-12$ to $\mathrm{H}_{2}-4$ (Figure 2) and protons were correlated by interpretation of COSY NMR data. The H-5 oxymethine was considerably deshielded $\left(\delta_{\mathrm{H}} 4.25\right)$ and showed correlations to $\mathrm{H}_{2}-4\left(\delta_{\mathrm{H}} 2.58,2.17\right)$ and an $\mathrm{HMBC}$ correlation to $\mathrm{C}-1\left(\delta_{\mathrm{C}} 167.7\right)$. The $\mathrm{H}_{2}-4$ methylene group showed HMBC correlations to an extremely polarized olefin $\left(\mathrm{C}-3, \delta_{\mathrm{C}} 173.3 ; \mathrm{C}-2, \delta_{\mathrm{C}} 90.3\right)$, and H-4a showed an HMBC correlation to C-1. An HMBC correlation from the $\mathrm{H}_{3}-24$ methoxy group to C-3 completed the characterization of an $\alpha, \beta$-unsaturated $\delta$-lactone with a methoxy group at the $\beta$ position. This functionalized lactone satisfied the 3 remaining degrees of unsaturation and completed the planar structure of $\mathbf{1}$.

HRESIMS analysis of 2 gave an $[\mathrm{M}+\mathrm{H}]^{+}$of $m / z 399.1853$, suggesting the molecular formula of $\mathrm{C}_{22} \mathrm{H}_{32} \mathrm{Cl}_{2} \mathrm{O}_{2}$ and a requirement of 6 degrees of unsaturation for this molecule. Using correlative 
information from 1D and 2D NMR experiments for 2, a polyketide chain was constructed from position 3 to position 22 in 2 nearly identical to that of position 4 to position 23 in trichophycin B (1) (cf. Tables 2 and 3). However, in 2 the oxygen-bearing carbon (C-4) is not part of a lactone ring functionality

Table 1. NMR data for trichophycin B (1)

\begin{tabular}{|c|c|c|c|c|c|}
\hline position & $\delta_{\mathrm{C}}$, type & $\delta_{\mathrm{H}}(J$ in $\mathrm{Hz})$ & HMBC & COSY & NOESY \\
\hline 1 & $167.7, \mathrm{C}$ & & & & \\
\hline 2 & $90.3, \mathrm{CH}$ & $5.13, \mathrm{~d}(1.6)$ & $1,3,4$ & & 24 \\
\hline 3 & $173.3, \mathrm{C}$ & & & & \\
\hline $4 a$ & $30.3, \mathrm{CH}_{2}$ & 2.58, ddd $(17.0,12.9,1.7)$ & $1,2,3,5,6$ & $4 b, 5$ & $7 \mathrm{a}, 7 \mathrm{~b}, 23$ \\
\hline $4 b$ & & 2.17, ovlp $^{\mathrm{b}}$ & $2,3,5,6$ & $4 a, 5$, & 23 \\
\hline 5 & $79.0, \mathrm{CH}$ & $4.25, \mathrm{dt}(12.9,3.9)$ & $1,3,4,6,7,23$ & $4 a, 4 b, 6$ & $7 b, 8,23$ \\
\hline 6 & $33.9, \mathrm{CH}$ & $1.83, \mathrm{~m}$ & $5,7,23$ & $5,7 \mathrm{a}, 7 \mathrm{~b}, 23$ & $4 a, 22$ \\
\hline $7 \mathrm{a}$ & $39.7, \mathrm{CH}_{2}$ & 1.46, ddd $(13.5,8.3,5.7)$ & $5,6,8,9,22,23$ & $6,7 b$ & $4 a$ \\
\hline $7 b$ & & 1.08, ddd $(13.5,8.5,5.5)$ & $5,6,8,9,22,23$ & $6,7 \mathrm{a}, 8$ & $4 a, 5$ \\
\hline 8 & $29.8, \mathrm{CH}$ & $1.49, \mathrm{~m}$ & $7,9,10,22$ & $9 b, 22$ & $5,11,23$ \\
\hline $9 \mathrm{a}$ & $31.7, \mathrm{CH}_{2}$ & 1.30, ovlp & $8,10,11,22$ & $9 b, 10 a$ & $12 \mathrm{a}$ \\
\hline $9 b$ & & $1.14, \mathrm{~m}$ & $8,10,11,22$ & $8,9 \mathrm{a}$ & 11 \\
\hline $10 \mathrm{a}$ & $34.1, \mathrm{CH}_{2}$ & $1.42, \mathrm{~m}$ & 9,11 & $10 b, 11$ & $12 b$ \\
\hline $10 b$ & & 1.30, ovlp & 9,11 & $10 \mathrm{a}, 11$ & \\
\hline 11 & $69.2, \mathrm{CH}$ & $3.60, \mathrm{~m}$ & $9,10,12,13$ & $10 \mathrm{a}, 12 \mathrm{~b}$ & $8,9 b, 21$ \\
\hline $12 \mathrm{a}$ & $42.7, \mathrm{CH}_{2}$ & 2.17, ovlp & $10,11,13,14,21$ & 11 & $9 a, 21$ \\
\hline $12 b$ & & 2.07, dd $(14.4,9.0)$ & $10,11,13,14,21$ & 11 & $10 \mathrm{a}, 21$ \\
\hline 13 & $138.7, \mathrm{C}$ & & & & \\
\hline $14 \mathrm{a}$ & $36.3, \mathrm{CH}_{2}$ & $3.75, \mathrm{~d}(14.4)$ & $12,13,15,16,20,21$ & $14 b$ & 16,20 \\
\hline $14 b$ & & $3.51, \mathrm{~d}(14.4)$ & $12,13,15,16,20,21$ & $14 \mathrm{a}$ & 16,20 \\
\hline 15 & $138.2, \mathrm{C}$ & & & & \\
\hline 16 & 128.7. CH & 7.22, ovlp & 14,18 & 17 & $14 a, 14 b$ \\
\hline 17 & $128.6, \mathrm{CH}$ & $7.29, \mathrm{t}(7.6)$ & 15 & & 16 \\
\hline 18 & $126.5, \mathrm{CH}$ & 7.22, ovlp & 16,20 & & \\
\hline 19 & $128.6, \mathrm{CH}$ & $7.29, \mathrm{t}(7.6)$ & 15 & & 20 \\
\hline 20 & $128.7, \mathrm{CH}$ & 7.22, ovlp & 14,18 & 19 & $14 a, 14 b$ \\
\hline 21 & $115.4, \mathrm{CH}$ & $6.07, \mathrm{~s}$ & $12,13,14$ & & $11,12 \mathrm{a}, 12 \mathrm{~b}$ \\
\hline 22 & $20.3, \mathrm{CH}_{3}$ & $0.85, \mathrm{~d}(6.4)$ & $7,8,9$ & 8 & $6,7 b, 9 a$ \\
\hline 23 & $14.9, \mathrm{CH}_{3}$ & $0.97, \mathrm{~d}(6.8)$ & $5,6,7$ & 6 & $4 a, 4 b, 5,8$ \\
\hline 24 & $56.0, \mathrm{CH}_{3}$ & $3.74, \mathrm{~s}$ & 3 & & 2 \\
\hline
\end{tabular}

as it is in $\mathbf{1}$ as the more shielded oxymethine proton in $\mathbf{2}\left(\mathrm{H}-4, \delta_{\mathrm{H}} 3.45\right)$ compared to that of $\mathbf{1}(\mathrm{H}-$ $\left.5, \delta_{\mathrm{H}} 4.25\right)$ supported the free secondary alcohol. Whereas $\mathbf{1}$ is hallmarked by an extended polyketide chain which ultimately terminates in a lactone ring, the allylic methylene protons at position 3 in $2\left(\mathrm{H}_{2}-3, \delta_{\mathrm{H}} 2.24,2.13\right)$ showed $\mathrm{HMBC}$ correlations to a polarized olefin with 
chemical shifts consistent with that of a terminal vinyl chloride functionality. The C-1/C-2 olefin in 2 was determined to be $E$ by virtue of a large vicinal ${ }^{1} \mathrm{H}-{ }^{1} \mathrm{H}$ coupling constant $(13.2 \mathrm{~Hz})$. NOE correlations established the chlorovinylidene group adjacent to the phenyl moiety as $E$ in trichophycin C (2), identical to that of $\mathbf{1}$.

HRESIMS analysis of $\mathbf{3}$ gave an $[\mathrm{M}+\mathrm{H}]^{+}$of $m / z, 375.1855$, suggesting a molecular formula of $\mathrm{C}_{20} \mathrm{H}_{32} \mathrm{Cl}_{2} \mathrm{O}_{2}$ and a requirement of 4 degrees of unsaturation. Examination of the ${ }^{13} \mathrm{C}$ NMR spectrum of $\mathbf{3}$ showed nearly identical signals to trichophyin C (2), with the exception of aromatic carbon signals, which were absent in 3 (Table 3). ${ }^{1} \mathrm{H}^{-13} \mathrm{C}$ and ${ }^{1} \mathrm{H}-{ }^{-1} \mathrm{H}$ correlations were made following interpretation of HMBC and COSY spectra, respectively, and established a partial structure of $\mathbf{3}$ identical to that of $\mathbf{2}$ from position 1 to position 12. Correlation analysis showed that the allylic methylene group $\mathrm{H}_{2}-13$ was coupled to a more shielded methylene group $\left(\mathrm{H}_{2}-14, \delta_{\mathrm{H}} 1.69\right)$. Additionally, correlations showed that the $\mathrm{H}_{2}-14$ methylene group was coupled to a second deshielded methylene group $\left(\mathrm{H}_{2}-15, \delta_{\mathrm{H}} 2.24\right)$. This methylene group showed HMBC correlations to the C-16 quaternary carbon $\left(\delta_{\mathrm{C}} 83.9\right)$ and a carbon $\left(\mathrm{C}-17, \delta_{\mathrm{C}} 68.8\right)$ with an attached proton at $\delta 1.99$ establishing an alkyne functionality and completing the planar structure of trichophycin D (3). The NOE correlations and ${ }^{1} \mathrm{H}-{ }^{1} \mathrm{H}$ vicinal coupling constants showed that the chlorovinylidene and terminal vinyl chloride groups in $\mathbf{3}$ and had identical geometry to those in 2.

HRESIMS analysis of $\mathbf{4}$ gave an $[\mathrm{M}+\mathrm{H}]^{+}$of $\mathrm{m} / \mathrm{z}$ 453.0961, suggesting a molecular formula of $\mathrm{C}_{20} \mathrm{H}_{32} \mathrm{BrCl}_{2} \mathrm{O}_{2}$ and a requirement of 4 degrees of unsaturation. Examination of ${ }^{1} \mathrm{H}$ and ${ }^{13} \mathrm{C}$ NMR signals showed that $\mathbf{4}$ was nearly identical in structure to $\mathbf{3}$ with the exception of the alkyne functionality (cf. Tables 2 and 3 ). The C-17 signal in 4 ( $\left.\delta_{\mathrm{C}} 38.4\right)$ showed no proton attachment and was tremendously shifted upfield from that in $\mathbf{3}\left(\delta_{\mathrm{C}} 68.8\right)$. The upfield shift of C-16 $\left(\delta_{\mathrm{C}} 83.9\right.$ 
in $\mathbf{3}, \delta_{\mathrm{C}} 79.9$ in 4 ) and the information gained from mass spectrometric analysis strongly supported an alkynyl bromide functionality in trichophycin E (4). The relative configurations of $\mathbf{4}$ were identical to that of $\mathbf{3}$. An alkynyl bromide functionality is also found in the mixed polyketide-peptide jamaicamide $\mathrm{A}$ and the alkyne signals in trichophycin $\mathrm{E}\left(\delta_{\mathrm{C}} 79.9\right.$ and 38.4) matched those of jamaicamide A quite well ( $\delta_{\mathrm{C}} 79.9$ and 38.2). ${ }^{13}$

Table 2. ${ }^{1} \mathrm{H}$ NMR for trichophycins C-E (2-4) $\left(800 \mathrm{MHz}, \mathrm{CDCl}_{3}\right)$

\begin{tabular}{|c|c|c|c|}
\hline \multicolumn{2}{|r|}{2} & \multirow{2}{*}{$\begin{array}{c}3 \\
\delta_{\mathrm{H}}(J \text { in } \mathrm{Hz})\end{array}$} & \multirow{2}{*}{$\begin{array}{c}4 \\
\delta_{\mathrm{H}}(J \text { in } \mathrm{Hz}) \\
\end{array}$} \\
\hline pos & $\delta_{\mathrm{H}}(J$ in $\mathrm{Hz})$ & & \\
\hline 1 & $6.04, d(13.2)$ & $6.05, d(13.2)$ & $6.05, d(13.2)$ \\
\hline 2 & $5.94, \mathrm{~m}$ & $5.96, \mathrm{~m}$ & $5.95, \mathrm{~m}$ \\
\hline $3 \mathrm{a}$ & $2.24, \mathrm{~m}$ & $2.25, \mathrm{~m}$ & 2.25, ovlp \\
\hline $3 b$ & $2.13, \mathrm{~m}$ & $2.14, \mathrm{~m}$ & 2.14, ovlp \\
\hline 4 & 3.45 , ddd $(8.7,5.3,3.4)$ & 3.47 , ddd $(8.8,5.2,3.4)$ & 3.47, ddd $(8.8,5.2,3.4)$ \\
\hline 5 & $1.63, \mathrm{~m}$ & 1.68, ovlp & 1.67, ovlp \\
\hline $6 \mathrm{a}$ & 1.35 , ddd $(13.3,9.0,4.5)$ & 1.40, ddd $(13.3,8.6,4.5)$ & 1.40, ovlp \\
\hline $6 \mathrm{~b}$ & 0.96, ddd $(13.5,9.4,5.5)$ & $1.00, \operatorname{ddd}(13.5,9.1,5.4)$ & $1.00, \mathrm{ddd}(14.0,9.2,5.5)$ \\
\hline 7 & $1.46, \mathrm{~m}$ & $1.53, \mathrm{~m}$ & $1.53, \mathrm{~m}$ \\
\hline $8 \mathrm{a}$ & 1.30, ovlp & 1.40, ovlp & 1.40, ovlp \\
\hline $8 \mathrm{~b}$ & $1.10, \mathrm{~m}$ & $1.20, \mathrm{~m}$ & $1.20, \mathrm{~m}$ \\
\hline $9 \mathrm{a}$ & $1.41, \mathrm{~m}$ & $1.49, \mathrm{~m}$ & $1.50, \mathrm{~m}$ \\
\hline $9 \mathrm{~b}$ & 1.30, ovlp & 1.40, ovlp & 1.40, ovlp \\
\hline 10 & $3.60, \mathrm{~m}$ & $3.68, \mathrm{~m}$ & $3.68, \mathrm{~m}$ \\
\hline $11 \mathrm{a}$ & 2.17, dd $(14.3,3.6)$ & $2.27, \mathrm{~m}$ & 2.26, ovlp \\
\hline $11 \mathrm{~b}$ & 2.07, dd $(14.3,8.9)$ & 2.13, ovlp & 2.12, ovlp \\
\hline \multicolumn{4}{|l|}{12} \\
\hline $13 \mathrm{a}$ & $3.75, \mathrm{~d}(14.4)$ & $2.44, \mathrm{~m}$ & $2.42, \mathrm{~m}$ \\
\hline $13 \mathrm{~b}$ & $3.51, \mathrm{~d}(14.4)$ & 2.25, olvp & 2.24, ovlp \\
\hline 14 & & 1.69, ovlp & 1.69, ovlp \\
\hline 15 & 7.21, ovlp & 2.24, ovlp & 2.25, ovlp \\
\hline 16 & $7.30, t(7.2)$ & & \\
\hline 17 & 7.22, ovlp & $1.99, \mathrm{t}(2.6)$ & \\
\hline 18 & $7.30, t(7.2)$ & $5.94, \mathrm{~s}$ & $5.94, \mathrm{~s}$ \\
\hline 19 & 7.21, ovlp & 0.91, ovlp & $0.91, \mathrm{~d}(6.6)$ \\
\hline 20 & $6.07, \mathrm{~s}$ & 0.90, ovlp & $0.90, \mathrm{~d}(6.8)$ \\
\hline 21 & $0.87, \mathrm{~d}(6.6)$ & & \\
\hline 22 & $0.86, \mathrm{~d}(6.4)$ & & \\
\hline
\end{tabular}


Table 3. ${ }^{13} \mathrm{C}$ NMR for trichophycins C-E (2-4) $\left(200 \mathrm{MHz}, \mathrm{CDCl}_{3}\right)$

\begin{tabular}{|c|c|c|c|c|}
\hline & 2 & 3 & 4 & $\Delta \delta^{13} \mathrm{C}(2-3 ; 2-4)$ \\
\hline pos & $\delta \mathrm{c}$, type & $\delta \mathrm{c}$, type & $\delta \mathrm{c}$, type & \\
\hline 1 & $119.2, \mathrm{CH}$ & $119.2, \mathrm{CH}$ & 119.2, CH & $0.0 ; 0.0$ \\
\hline 2 & $130.7, \mathrm{CH}$ & $130.7, \mathrm{CH}$ & $130.7, \mathrm{CH}$ & $0.0 ; 0.0$ \\
\hline 3 & $35.0, \mathrm{CH}_{2}$ & $35.0, \mathrm{CH}_{2}$ & $35.1, \mathrm{CH}_{2}$ & $0.0 ;-0.1$ \\
\hline 4 & $74.8, \mathrm{CH}$ & $74.8, \mathrm{CH}$ & $74.8, \mathrm{CH}$ & $0.0 ; 0.0$ \\
\hline 5 & $35.8, \mathrm{CH}$ & $35.8, \mathrm{CH}$ & $35.8, \mathrm{CH}$ & $0.0 ; 0.0$ \\
\hline 6 & $39.8, \mathrm{CH}_{2}$ & $39.7, \mathrm{CH}_{2}$ & $39.8, \mathrm{CH}_{2}$ & $0.1 ; 0.0$ \\
\hline 7 & $30.1, \mathrm{CH}$ & $30.2, \mathrm{CH}$ & $30.2, \mathrm{CH}$ & $-0.1 ;-0.1$ \\
\hline 8 & $31.5, \mathrm{CH}_{2}$ & 31.6, $\mathrm{CH}_{2}$ & $31.6, \mathrm{CH}_{2}$ & $-0.1 ;-0.1$ \\
\hline 9 & $34.0, \mathrm{CH}_{2}$ & $34.1, \mathrm{CH}_{2}$ & $34.1, \mathrm{CH}_{2}$ & $-0.1 ;-0.1$ \\
\hline 10 & $69.2, \mathrm{CH}$ & $69.2, \mathrm{CH}$ & $69.3, \mathrm{CH}$ & $0.0 ;-0.1$ \\
\hline 11 & $42.8, \mathrm{CH}_{2}$ & $43.1, \mathrm{CH}_{2}$ & $43.1, \mathrm{CH}_{2}$ & $-0.3 ;-0.3$ \\
\hline 12 & 138.6, C & $138.9, \mathrm{C}$ & $138.8, \mathrm{C}$ & $-0.3 ;-0.2$ \\
\hline 13 & $36.3, \mathrm{CH}_{2}$ & $29.4, \mathrm{CH}_{2}$ & $29.4, \mathrm{CH}_{2}$ & \\
\hline 14 & 138.2, C & $26.1, \mathrm{CH}_{2}$ & $25.9, \mathrm{CH}_{2}$ & \\
\hline 15 & $128.7, \mathrm{CH}$ & $18.4, \mathrm{CH}_{2}$ & 19.6, $\mathrm{CH}_{2}$ & \\
\hline 16 & 128.6, CH & $83.9, \mathrm{C}$ & 79.7, C & \\
\hline 17 & 126.6, CH & $68.8, \mathrm{CH}$ & $38.4, \mathrm{C}$ & \\
\hline 18 & 128.6, CH & $115.4, \mathrm{CH}$ & $115.4, \mathrm{CH}$ & \\
\hline 19 & $128.7, \mathrm{CH}$ & $20.7, \mathrm{CH}_{3}$ & $20.7, \mathrm{CH}_{3}$ & \\
\hline 20 & $115.5, \mathrm{CH}$ & $15.7, \mathrm{CH}_{3}$ & $15.8, \mathrm{CH}_{3}$ & \\
\hline 21 & $20.6, \mathrm{CH}_{3}$ & & & \\
\hline 22 & $15.7, \mathrm{CH}_{3}$ & & & \\
\hline
\end{tabular}

HRESIMS analysis of 5 gave an $[\mathrm{M}+\mathrm{H}]^{+}$of $m / z$ 454.2739, suggesting a molecular formula of $\mathrm{C}_{25} \mathrm{H}_{40} \mathrm{ClNO}_{4}$, and a requirement of 6 degrees of unsaturation. Examination of the ${ }^{1} \mathrm{H}$ NMR spectrum of $\mathbf{5}$ showed certain resonances with split signals in a 1:1 ratio. This phenomenon has been observed in several cyanobacteria metabolites with methylated tertiary amides such as smenamides A and B and kalkitoxin. ${ }^{19,20}$ After examining NOE correlations, these split signal effects were determined to be the result of conformers in the $E$ and $Z$ configuration at a tertiary amide functionality in 5. 1D and 2D NMR analysis of 5, led to the assignment of a partial structure that was identical to that of trichophycin B (1) from C-1 to C-9 including the methyl branches at C-6 and C-8 (Table 4). In a second partial structure, a moderately deshielded 
diastereotopic methylene group $\left(\mathrm{H}_{2}-14, \delta_{\mathrm{H}} 2.19\right)$ was correlated by interpretation of COSY spectra to a second methylene group $\left(\mathrm{H}_{2}-15, \delta_{\mathrm{H}} 1.63\right)$ which itself was correlated to a third methylene group $\left(\mathrm{H}_{2}-16, \delta_{\mathrm{H}} 3.34\right)$. This deshielded methylene was correlated by examination of HMBC spectra to C-20 $\left(\delta_{\mathrm{C}} 34.4\right)$ and the C-17 carbonyl $\left(\delta_{\mathrm{C}} 173.4\right)$. A methylene $\left(\mathrm{H}_{2}-18, \delta_{\mathrm{H}} 2.33\right)$ and methyl triplet $\left(\mathrm{H}_{3}-19, \delta_{\mathrm{H}} 1.06\right)$ showed an $\mathrm{HMBC}$ correlation to $\mathrm{C}-17$ and characterized the western half of 5 with an $\mathrm{N}$-methyl propanamide functionality. $\mathrm{H}_{2}-14$ showed HMBC correlations to $\mathrm{C}-13\left(\delta_{\mathrm{C}} 142.2\right)$ and C-21 $\left(\delta_{\mathrm{C}} 112.6\right)$ establishing the chlorovinylidene moiety of the trichophycins. NOE correlations from H-21 to H-11 supported the chlorovinylidene configuration as $E$. The chemical shift value at C-22 $\left(\delta_{\mathrm{C}} 15.0\right)$ and NOE correlations from H-11 to $\mathrm{H}_{2}-9$ and $\mathrm{H}_{3}-22$ to $\mathrm{H}_{2}-12$ supported an $E$ configuration of $\mathrm{C} 10 / \mathrm{C} 11$ olefin. $\mathrm{H}_{2}-12\left(\delta_{\mathrm{H}} 2.85\right)$ showed HMBC correlations to C-13 and C-21 as well as C-11 $\left(\delta_{\mathrm{C}} 121.9\right)$ and the $\mathrm{C}-10$ quaternary carbon $\left(\delta_{\mathrm{C}} 136.8\right)$. A methyl correlated to $\mathrm{C}-10$ by $\mathrm{HMBC}\left(\mathrm{H}_{3}-22\left(\delta_{\mathrm{H}} 1.63\right)\right.$ and an HMBC correlation from $\mathrm{H}_{2}-9$ to $\mathrm{C}-10$ connected to two partial structures and completed the planar structure of $\mathbf{5}$.

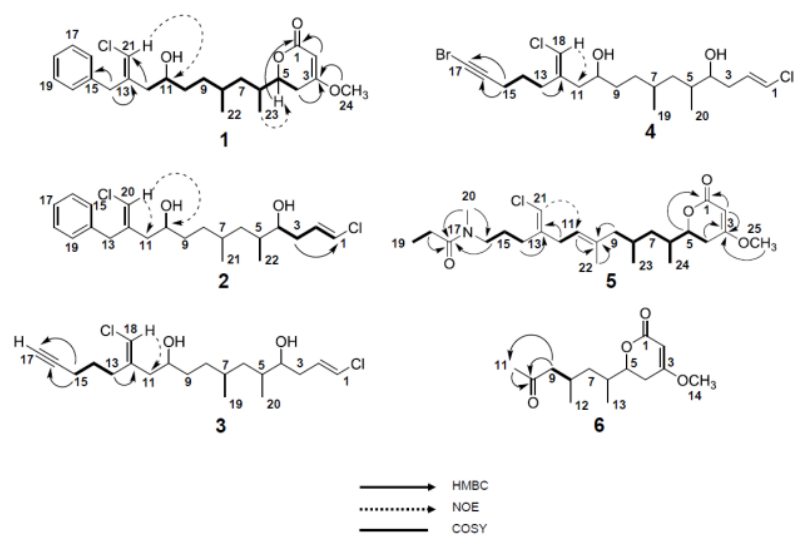

Figure 2. Selected 2D NMR correlations of 1-6.

HRESIMS analysis of 6 gave an $[\mathrm{M}+\mathrm{H}]^{+}$of $m / z, 255.1595$, suggesting a molecular formula of $\mathrm{C}_{14} \mathrm{H}_{22} \mathrm{O}_{4}$ and a requirement of 4 degrees of unsaturation. NMR analysis determined that 6 
contained the functionalized lactone moiety present in $\mathbf{1}$ and supported an identical planar structure from C-1 to C-8 in $\mathbf{6}$ as that from C-1 to C-8 in $\mathbf{1}$ including the position of the methyl groups (Table S2). However, in 6, a deshielded methylene group $\left(\mathrm{H}_{2}-9, \delta_{\mathrm{H}} 2.44\right.$ and 2.18) showed HMBC correlations to C-8 and a carbonyl at C-10 ( $\left.\delta_{\mathrm{C}} 208.9\right)$. A considerably deshielded methyl group at $\mathrm{H}_{3}-11\left(\delta_{\mathrm{H}} 2.08\right)$ showed HMBC correlations to C-10 and C-9 and completed the planar structure of tricholactone (6).

Table 4. NMR data for trichophycin F (5) Z-conformer ( $800 \mathrm{MHz}$ for ${ }^{1} \mathrm{H} \mathrm{NMR} ; 200 \mathrm{MHz}$ for $\left.{ }^{13} \mathrm{C} \mathrm{NMR}^{\mathrm{N}} \mathrm{CD}_{3} \mathrm{CN}\right)$

\begin{tabular}{|c|c|c|c|c|c|}
\hline position & $\delta_{\mathrm{c}}$, type & $\delta_{\mathrm{H}}(J$ in $\mathrm{Hz})$ & HMBC & COSY & NOESY \\
\hline 1 & 167.0, C & & & & \\
\hline 2 & $89.6, \mathrm{CH}$ & $5.11, \mathrm{~s}$ & $1,3,4$ & $4 a$ & 25 \\
\hline 3 & $173.9, \mathrm{C}$ & & & & \\
\hline $4 a$ & $30.0, \mathrm{CH}_{2}$ & 2.60, dd $(17.0,13.0)$ & $2,3,5,6$ & $2,4 b, 5$ & $4 b, 24$ \\
\hline $4 b$ & & 2.24 , ddd $(17.0,3.6,1.3)$ & $2,3,5$ & $4 a, 5$ & $4 a$ \\
\hline 5 & 78.7, $\mathrm{CH}$ & $4.30, \mathrm{dt}(13.0,3.9)$ & $3,4,6,7,24$ & $4 a, 4 b, 6$ & $4 \mathrm{a}, 4 \mathrm{~b}, 7 \mathrm{a}, 8,24$ \\
\hline 6 & $33.7, \mathrm{CH}$ & $1.88, \mathrm{~m}$ & $5,7,24$ & 24 & 23,24 \\
\hline $7 \mathrm{a}$ & $39.8, \mathrm{CH}_{2}$ & $1.45, \mathrm{~m}$ & $5,6,8,9,22,23$ & $6,7 b, 8$ & $7 b$ \\
\hline $7 b$ & & $1.07, \mathrm{~m}$ & $5,6,8,9,22,23$ & $6,7 \mathrm{a}$ & $7 \mathrm{a}$ \\
\hline 8 & $27.5, \mathrm{CH}$ & $1.75, \mathrm{~m}$ & 7,9 & $9 a, 23$ & $5,7 \mathrm{a}, 23,24$ \\
\hline $9 \mathrm{a}$ & $46.9, \mathrm{CH}_{2}$ & $2.10, \mathrm{~m}$ & $7,8,10,11,23$ & $9 b$ & $9 \mathrm{a}$ \\
\hline $9 b$ & & 1.74, ovlp $^{\mathrm{a}}$ & $7,8,10,11,23$ & $9 \mathrm{a}$ & $9 b$ \\
\hline 10 & $136.8, \mathrm{C}$ & & & & \\
\hline 11 & $121.9, \mathrm{CH}$ & $5.14, \mathrm{~m}$ & $9,12,22$ & 12,22 & $9 a, 9 b, 12$ \\
\hline 12 & $33.0, \mathrm{CH}_{2}$ & $2.85, \mathrm{~m}$ & $10,11,13,21$ & 11,21 & 22 \\
\hline 13 & $142.2, \mathrm{C}$ & & & & \\
\hline 14 & $27.8, \mathrm{CH}_{2}$ & 2.19, ovlp & $12,13,15,16$ & 15 & \\
\hline 15 & $24.6, \mathrm{CH}_{2}$ & $1.63, \mathrm{~m}$ & $13,14,16$ & 14,16 & \\
\hline 16 & $47.5, \mathrm{CH}_{2}$ & $3.34, \mathrm{td},(7.1,1.7)$ & $14,15,17,20$ & 15 & 15,20 \\
\hline 17 & $173.4, \mathrm{C}$ & & & & \\
\hline 18 & $26.2, \mathrm{CH}_{2}$ & $2.33, \mathrm{~m}$ & 17,19 & 19 & 19,20 \\
\hline 19 & $9.0, \mathrm{CH}_{3}$ & $1.06, \mathrm{t}(7.4)$ & 17,18 & 18 & 18 \\
\hline 20 & $34.4, \mathrm{CH}_{3}$ & $2.97, \mathrm{~s}$ & 16,17 & & $15,16,18$ \\
\hline 21 & $112.6, \mathrm{CH}$ & $5.92, \mathrm{~s}$ & $12,13,14$ & 12 & 11,12 \\
\hline 22 & $15.0, \mathrm{CH}_{3}$ & $1.63, \mathrm{~s}$ & $9,10,11$ & 11 & 12 \\
\hline 23 & $19.6, \mathrm{CH}_{3}$ & $0.86, \mathrm{~d}(6.3)$ & $7,8,9$ & 8 & $6,7 \mathrm{a}, 7 \mathrm{~b}, 8$ \\
\hline 24 & $14.3, \mathrm{CH}_{3}$ & $0.99, \mathrm{~d}(6.8)$ & $5,6,7$ & 6 & $4 a, 5,6,8$ \\
\hline 25 & $56.0, \mathrm{CH}_{3}$ & $3.75, \mathrm{~s}$ & 3 & & 2 \\
\hline
\end{tabular}

${ }^{\text {a }}$ overlapping signals

Stereochemical assignment of 1 . The absolute configuration assignment of the trichophycins was challenging due to the occurrence of non-adjacent secondary alcohol groups in compounds 
$\mathbf{2 - 4}$, the presence of multiple stereocenters, and highly overlapped methylene regions in the 1D ${ }^{1} \mathrm{H}$ NMR data.

Initial work to address this challenge began with assignment of the absolute configuration for the C-11 center of $\mathbf{1}$. This was determined by a modified Mosher's esterification procedure ${ }^{21}$ using two equal portions of 1 that were acylated with $R$-(-)-and $S$-(+)- $\alpha$-methoxy- $\alpha$ (trifluoromethyl)phenylacetyl chloride ( $\alpha$-MTPA-Cl). These reactions yielded the C-11 $R$ ester from $(S)$-MTPA-Cl and the C-11 $S$ ester from $(R)$-MTPA-Cl. Examination of the $1 \mathrm{D}^{1} \mathrm{H}$ NMR and ${ }^{1} \mathrm{H}-{ }^{1} \mathrm{H}$ TOCSY spectra of the individual esters allowed calculation of $\Delta\left(\delta_{\mathrm{H}} S-\delta_{\mathrm{H}} R\right)$ values. These results showed negative $\Delta\left(\delta_{\mathrm{H}} S-\delta_{\mathrm{H}} R\right)$ values for $\mathrm{H}-21, \mathrm{H}-14 \mathrm{a}, \mathrm{H}-14 \mathrm{~b}, \mathrm{H}-12 \mathrm{a}$ and $\mathrm{H}-12 \mathrm{~b}$ and positive $\Delta\left(\delta_{\mathrm{H}} S-\delta_{\mathrm{H}} R\right)$ values for H-10a, H-10b, H-9a, H-9b, H-8, H-7a, H-7b, H-4a, H-4b, and H22 thus supporting an $11 R$ configuration. The configuration of C-5 in 1, 5 and $\mathbf{6}$ was assigned as $R$ following determination of the axial orientation of $\mathrm{H}-5$ (large vicinal coupling constant between $\mathrm{H}-5$ and $\mathrm{H}-4 \mathrm{a}, J=13.0 \mathrm{~Hz}$ ) and examination of ECD spectra of each compound which showed a positive $\mathrm{n} \rightarrow \pi$ Cotton effect at $244 \mathrm{~nm}$ (Figures S43-S45). The stereochemistry at C-5 in these compounds was determined using the rules of Snatzke and Beecham ${ }^{22,23}$ coupled with a comparison of ECD curves of previously characterized similar molecules. ${ }^{24,25}$

The absolute configurations at C-6 and C-8 in 1 were addressed by application of the $J$-based configuration analysis method and supported by DFT calculations, which were performed for the four possible stereo-configurations, i.e. C11RC8SC6SC5R, C11RC8SC6RC5R, C11RC8RC6SC5R and C11RC8RC6RC5R. The configurations at C-11 and C-5 were kept fixed in each case. Briefly, 200 conformers generated through a previously described procedure ${ }^{26}$ were submitted to Gaussian 09 for geometry optimization at the B3LYP/6-31g(d,p) level of theory. Vibrational frequencies were calculated with the "freq" Gaussian keyword. After discarding 
redundant structures and structures with imaginary frequencies, the remaining conformers were ranked based on the sum of electronic and thermal free energies. For those conformers whose energies were within the $2.2 \mathrm{kcal} / \mathrm{mol}$ window of the lowest energy conformer, $J$-couplings were calculated in Gaussian 09 at the B3LYP/6-311+g(d,p) level of theory; the "mixed" Gaussian keyword was used to request a two-step coupling calculation. ${ }^{27}$ Finally, the $J$-couplings were averaged across the lowest energy conformers based on their calculated Boltzmann populations. The number of conformers used for $J$-coupling averaging and their respective Boltzmann distributions for each diastereomer are listed in Table 5.

Table 5. Conformational distribution of different diastereomers of $\mathbf{1}$

\begin{tabular}{cc}
\hline Stereochemistry & Number of lowest energy conformers (Boltzmann Populations, \%) \\
\hline C8SC6S & $12(48.7,15.3,8.6,5.9,5.7,3.8,3.6,2.1,1.7,1.7,1.6,1.4)$ \\
C8SC6R & $9(57.5,30.5,2.8,1.9,1.7,1.5,1.5,1.4,1.2)$ \\
C8RC6S & $8(43.3,32.7,7.1,5.2,4.2,3.3,2.7,1.6)$ \\
C8RC6R & $12(53.9,9.2,7.6,6.9,5.6,4.0,3.4,2.9,1.8,1.7,1.5,1.4)$ \\
\hline
\end{tabular}

Key calculated coupling constants obtained from the DFT calculations were compared to experimental $J$-coupling values measured using a variety of NMR experiments such as PSYCHEDELIC ${ }^{28}$ for the determination of ${ }^{1} \mathrm{H}-{ }^{1} \mathrm{H}$ coupling constants and HSQC-TOCSY IPAP,${ }^{29}$ sel-HSQMBC IPAP, ${ }^{30}$ and HMBC IPAP ${ }^{31}$ for the measurement of long-range ${ }^{1} \mathrm{H}-{ }^{13} \mathrm{C}$ coupling constants. Unfortunately, the number of relevant experimental couplings that could be measured from all these techniques was still somewhat limited. Nonetheless, as shown in Table 6, a unique and optimal fit appeared for the $\mathrm{C} 11 R \mathrm{C} 8 R \mathrm{C} 6 \mathrm{RC} 5 \mathrm{R}$ configuration. This assignment was strengthened based on the key ${ }^{2} \mathbf{J}_{\mathrm{H} 6-\mathrm{C} 5}$ coupling, which was measured to be a "small" value (< $2 \mathrm{~Hz}$ ) that was only compatible with the proposed configuration (Table 6, shaded line). 
To further bolster the preliminary stereochemical assignment, we carefully examined the most stable conformers for each of the four possible configurations obtained from the DFT output and carefully analyzed the 2D NOESY data. According to DFT, a strong NOE between H-5 and H-8 should be expected for the $\mathrm{C} 8 R \mathrm{C} 6 R$ stereo-configuration, but not for the other three diastereomers.

Table 6. DFT [B3LYP/6-311+g(d,p)// B3LYP/6-31g(d,p)] analysis of $\mathbf{1 .}$

\begin{tabular}{cccccc}
\hline Coupling & C8SC6S & C8SC6R & C8RC6S & C8RC6R & Experimental \\
\hline H5 - H4a/H4b & $13.2 / 3.9$ & $14.5 / 3.9$ & $12.8 / 4.0$ & $14.0 / 3.7$ & $12.9 / 3.9$ \\
H5-H6 & 6.3 & 3.6 & 8.6 & 3.0 & 4.2 \\
H6 - H7a/H7b & $11.8 / 2.5$ & $11.7 / 4.3$ & $11.2 / 2.7$ & $10.7 / 5.5$ & $8.5 / 5.7$ \\
H8 - H7a/H7b & $12.1 / 3.2$ & $11.9 / 4.1$ & $11.9 / 3.1$ & $10.7 / 4.8$ & n.m. ${ }^{a} / 5.5$ \\
H6 - C5 & -6.0 & -6.1 & -5.4 & 0.7 & $<2.0$ \\
H6 - C4 & 4.1 & 5.5 & 2.4 & 2.0 & n.m. \\
H6 - C8 & 2.7 & 1.5 & 2.3 & 1.5 & n.m. \\
H8 - C6 & 2.1 & 1.5 & 2.1 & 1.7 & n.m. \\
H4a/H4b - C6 & $2.9 / 0.5$ & $2.7 / 0.3$ & $3.1 / 0.5$ & $2.4 / 0.6$ & $3.5 / 1.2$ \\
H7a/H7b - C5 & $4.2 / 1.4$ & $8.2 / 2.4$ & $3.2 / 2.2$ & $6.2 / 2.2$ & $4.2 / 4.0$ \\
\hline
\end{tabular}

${ }^{a}$ not measured

The $\left\langle\mathrm{R}^{-6}\right\rangle$ averaged distance of $\mathrm{H}-5-\mathrm{H}-8$ for $\mathrm{C} 8 R \mathrm{C} 6 \mathrm{R}$ among the lowest energy conformers within a $2.2 \mathrm{kcal} / \mathrm{mol}$ cut-off window was $2.2,4.2,3.5$ and $4.6 \AA$ for $\mathrm{C} 8 R \mathrm{C} 6 R, \mathrm{C} 8 R \mathrm{C} 6 S$, C8SC6R, and C8SC6S, respectively. Acquisition of a high-resolution 2D NOESY spectrum was required to overcome some overlapping issues, which in combination with a $1 \mathrm{D}$ selective NOE experiment, shown in Figure 3, provided clear evidence of an NOE correlation between H-5 and $\mathrm{H}-8$, thus further supporting the C $8 R \mathrm{C} 6 R \mathrm{C} 5 R$ stereochemistry.

Stereochemical assignment of 2. In analogy to the work done to assign the absolute configuration of $\mathbf{1}$, we were able to generate and analyze bis-MTPA esters of $\mathbf{2}$. Examination of the $1 \mathrm{D}{ }^{1} \mathrm{H}$ NMR and ${ }^{1} \mathrm{H}-{ }^{1} \mathrm{H}$ COSY spectra of the individual bis-esters allowed calculation of 
$\Delta\left(\delta_{\mathrm{H}} S-\delta_{\mathrm{H}} R\right)$ values. These results revealed negative $\Delta\left(\delta_{\mathrm{H}} S-\delta_{\mathrm{H}} R\right)$ values for $\mathrm{H}-19, \mathrm{H}-15, \mathrm{H}-13 \mathrm{a}$, H-20 and H-11 and positive $\Delta\left(\delta_{\mathrm{H}} S-\delta_{\mathrm{H}} R\right)$ values for $\mathrm{H}-9, \mathrm{H}-8, \mathrm{H}-7, \mathrm{H}-6 \mathrm{a}, \mathrm{H}-6 \mathrm{~b}, \mathrm{H}-5, \mathrm{H}-4, \mathrm{H}-21$ and $\mathrm{H}-22$. Additional negative $\Delta\left(\delta_{\mathrm{H}} S-\delta_{\mathrm{H}} R\right)$ values for $\mathrm{H}-3, \mathrm{H}-2$ and $\mathrm{H}-1$ supported configurations of $10 R$ and $4 S$.

A)

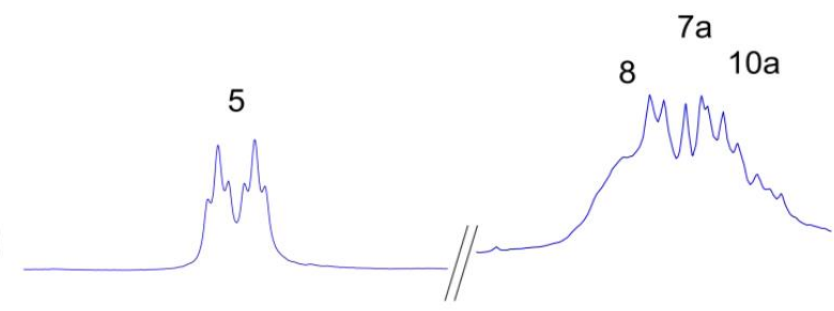

B)
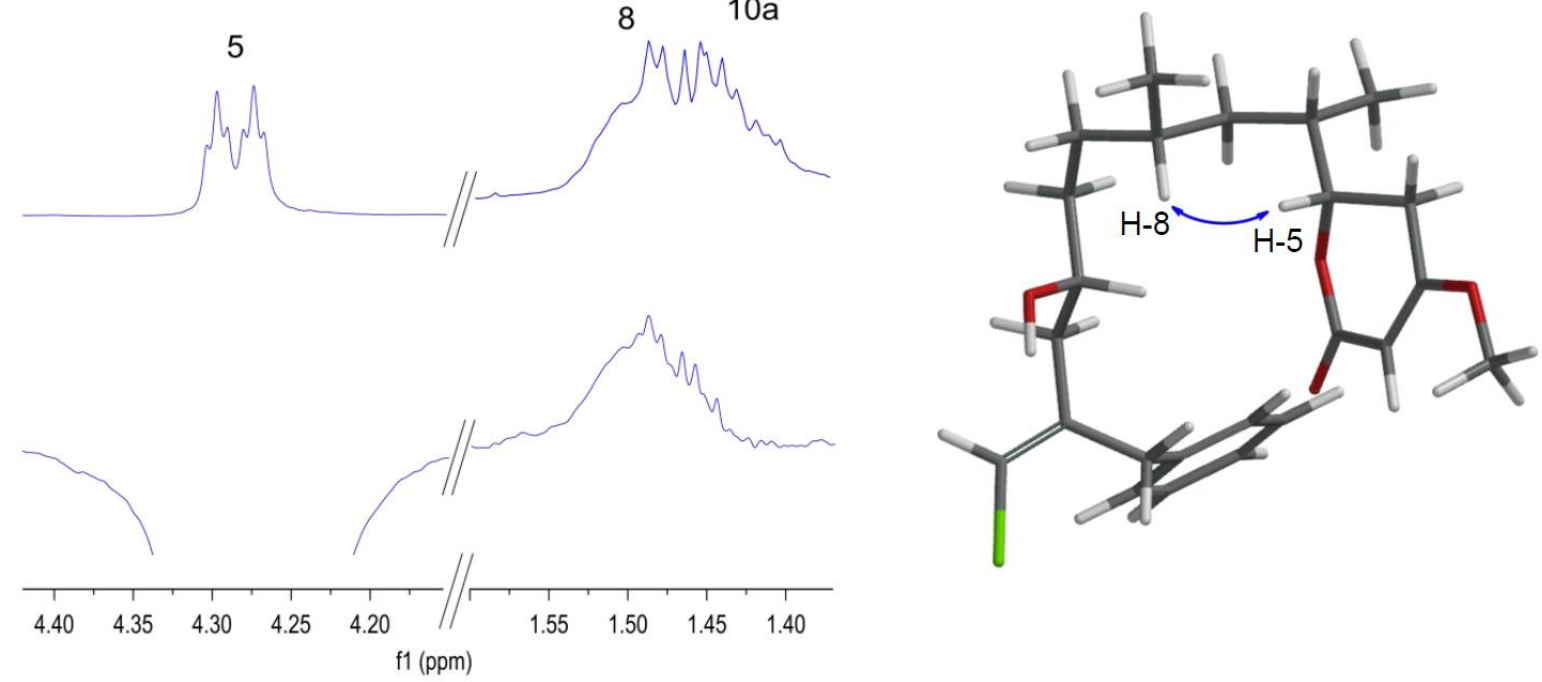

Figure 3. A) ${ }^{1} \mathrm{H}$ NMR spectrum of 1. B) 1D sel-NOE after inversion of H-5.

Initial analysis of ${ }^{3} J_{\mathrm{HH}}$ couplings indicated the $\mathbf{2}$ was quite flexible so the stereochemical assignment of C-7 and C-5 was carried out by $J$-based configuration analysis supplemented with computational modeling by DFT, similarly adopted from the work done for $\mathbf{1}$. Four different stereo-configurations were considered, including $\mathrm{C} 7 R \mathrm{C} 5 R, \mathrm{C} 7 R \mathrm{C} 5 \mathrm{~S}, \mathrm{C} 7 \mathrm{SC} 5 R$, and $\mathrm{C} 7 \mathrm{SC} 5 \mathrm{~S}$, with C-10 and C-4 fixed to $R$ and $S$, respectively. To better account for the flexibility of the molecule, geometry optimization was conducted at two different levels of theory in Gaussian 09, namely B3LYP/6-31g(d,p) and M062X/6-31g(d,p). These results are summarized in Table S3.

Calculation of $J$-couplings was performed as described previously for $\mathbf{1}$, and the averaged $J$ couplings are listed in Table 7 along with experimentally measured values. As is clearly shown 
in Table 7, the RMSD between theoretically calculated and experimentally measured $J$-couplings is the lowest for $\mathrm{C} 7 R \mathrm{C} 5 R$, using both B3LYP and MO62X functionals. The RMSDs of the other diastereomers are 2-3 fold larger. In Table $\mathrm{S} 4$ we compared the average $J$-couplings obtained from conformational distributions calculated at the B3LYP/6-31g $(\mathrm{d}, \mathrm{p})$ and MO62X/6-31g(d,p) levels of theory, in order to estimate the "error-bars" on the theoretical values. The relatively small RMSD between the theoretical couplings from B3LYP and MO62X, ranging from 0.7 to 1 $\mathrm{Hz}$ for the different stereoisomers, indicate good consistency between these two levels of theory.

Table 7. Comparison of experimentally measured $J$-couplings with theoretically calculated values for 2

\begin{tabular}{|c|c|c|c|c|c|c|c|c|c|}
\hline \multirow{2}{*}{ Coupling } & \multicolumn{4}{|c|}{ B3LYP/6-311+g(d,p)//B3LYP/6-31g(d,p) } & \multicolumn{4}{|c|}{ B3LYP/6-311+g(d,p)//MO62X/6-31g(d,p) } & \multirow{2}{*}{$\operatorname{Exp}(\mathrm{Hz})$} \\
\hline & C7SC5S & C7SC5R & C7RC5S & C7RC5R & C7SC5S & C7SC5R & C7RC5S & C7RC5R & \\
\hline H6a-C8 & 2.4 & 2.4 & 7.1 & 6.1 & 1.8 & 1.8 & 8.2 & 6.0 & 5.8 \\
\hline $\mathrm{H} 6 \mathrm{~b}-\mathrm{C} 21$ & 3.1 & 3 & 3.8 & 4.3 & 2.7 & 2.5 & 3.1 & 4.7 & 4.0 \\
\hline $\mathrm{H} 6 \mathrm{~b}-\mathrm{C} 22$ & 2.7 & 6.1 & 2.6 & 6.3 & 2.5 & 6.7 & 1.4 & 5.9 & 6.2 \\
\hline $\mathrm{H} 6 \mathrm{a}-\mathrm{H} 5$ & 8.4 & 9.1 & 11.2 & 9.2 & 10.0 & 10.1 & 11.8 & 8.5 & 9.4 \\
\hline $\mathrm{H} 6 \mathrm{~b}-\mathrm{C} 8$ & 5.1 & 5.1 & 2.2 & 3.1 & 3.7 & 4.6 & 2.1 & 3.2 & 3.8 \\
\hline $\mathrm{H} 6 \mathrm{a}-\mathrm{H} 7$ & 7.5 & 7.6 & 5.4 & 6.6 & 5.9 & 7.1 & 4.6 & 6.6 & 5.5 \\
\hline $\mathrm{H} 6 \mathrm{~b}-\mathrm{H} 7$ & 8.0 & 8.4 & 10.9 & 9.1 & 10.3 & 9.8 & 12.5 & 9.4 & 9.0 \\
\hline $\mathrm{H} 5-\mathrm{H} 4$ & 4.5 & 3.6 & 3.0 & 4.9 & 4.2 & 3.6 & 3.2 & 6.3 & 5.3 \\
\hline $\mathrm{H} 5-\mathrm{C} 3$ & 2 & 3.6 & 1.5 & 3.3 & 1.8 & 2.9 & 1.2 & 2.7 & 4.1 \\
\hline $\mathrm{H} 4-\mathrm{C} 6$ & 2.1 & 2.9 & 2.1 & 2.8 & 1.9 & 3.4 & 2.0 & 4.0 & 2.7 \\
\hline $\mathrm{H} 4-\mathrm{C} 22$ & 4.6 & 4.3 & 5.3 & 3.7 & 4.8 & 3.9 & 5.5 & 2.9 & 3.5 \\
\hline $\mathrm{H} 5-\mathrm{C} 4$ & $1.4^{\mathrm{a}}$ & $2.8^{\mathrm{a}}$ & 0.2 & $3.5^{\mathrm{a}}$ & $0.8^{\mathrm{a}}$ & $1.8^{\mathrm{a}}$ & 0.3 & $3.6^{\mathrm{a}}$ & 4.7 \\
\hline $\begin{array}{c}\text { RMSD } \\
(\mathrm{Hz})\end{array}$ & 2.1 & 1.6 & 2.2 & 0.7 & 2.2 & 1.8 & 2.7 & 0.9 & \\
\hline
\end{tabular}

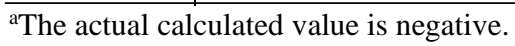

These results clearly favor C $7 R C 5 R$ as the correct stereoisomer for $\mathbf{2}$ and when taken together with the analysis of the Mosher esters support a $10 R, 7 R, 5 R, 4 S$ absolute configuration assignment for 2 (Figure 4).

The absolute configuration of $\mathbf{3}$ and $\mathbf{4}$ was proposed by analogy to $\mathbf{2}$ based on ${ }^{13} \mathrm{C}$ NMR chemical shifts of the stereogenic carbons (Table $3, \Delta \delta{ }^{13} \mathrm{C} \mathbf{2 - 3} ; \mathbf{2 - 4}$ values) and comparison of the relative 
configuration. The absolute configuration of C-5 in $\mathbf{5}$ and $\mathbf{6}$ was determined using ECD and remaining absolute configurations are proposed by relative configuration comparison to $\mathbf{1}$.

A)

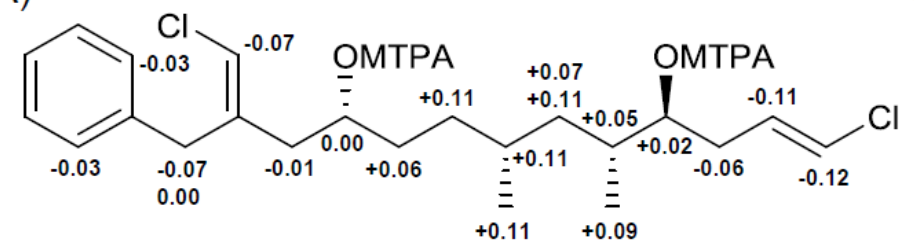

B)

$\begin{array}{llll}R, R, R, S & \underline{\mathrm{R}^{2} \mathrm{~B} 3 \mathrm{LYP}} & & \underline{\mathrm{R}^{2} \mathrm{MO}} \\ R, S, R, S & 0.8995 & 0.7988 \\ R, S, S, S & 0.5694 & 0.6219 \\ R, R, S, S & 0.4314 & 0.6055 \\ & 0.6586 & 0.6429\end{array}$

C)
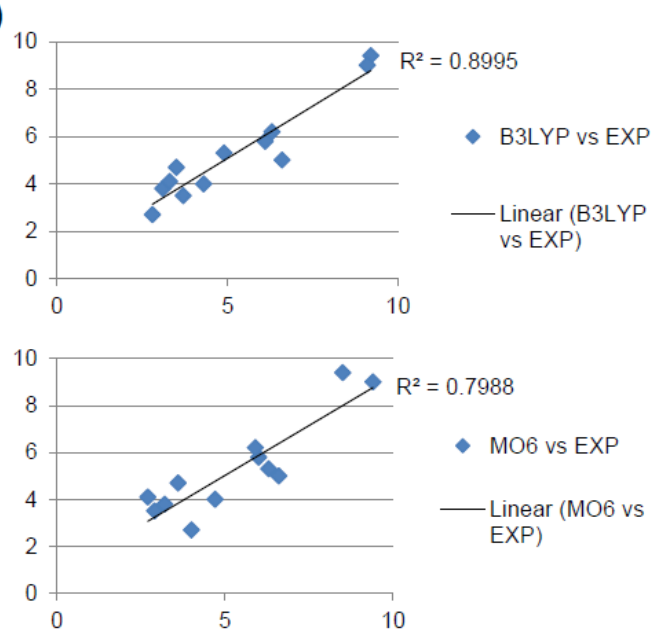

Figure 4. A) $\Delta \delta$ S-R values of bis-Mosher esters of 2. B) $\mathrm{R}^{2}$ values for correlations between theoretical and experimental $J$-couplings for stereoconfigurations at C-7 and C-5 implementing both the B3LYP and MO6 levels of theory (configurations at C-10 and C-4 were held fixed as $R$ and $S$, respectively. C) Plots of theoretical vs. experimental $J$-coupling values for C-7R and C-5R at the two levels of theory for 2 .

Cytotoxic Activity. Trichophycin B (1) had an $\mathrm{EC}_{50}$ value against neuro-2A cells of $14.8 \pm 2.4$ $\mu \mathrm{M}$. Trichophycin C (2) $\left(\mathrm{EC}_{50}: 23.8 \pm 4.2 \mu \mathrm{M}\right)$ was less potent. The alkyne-containing trichophycins showed less potent activity than those containing phenyl groups. Trichophycin D (3) had an $\mathrm{EC}_{50}$ value of $39.8 \pm 3.8 \mu \mathrm{M}$, while trichophycin $\mathrm{E}$ (4) showed low toxicity even at $100 \mu \mathrm{M}$ and was essentially non-toxic. Trichophycin F (5) showed moderate toxicity against neuro-2A cells $\left(\mathrm{EC}_{50}: 14.3 \pm 2.3 \mu \mathrm{M}\right)$ similar to that of $\mathbf{1}$. Tricholactone (6) degraded before it could be assessed for biological activity. Comparing the cytotoxicity of trichophycin C (2) in this study $\left(\mathrm{EC}_{50}\right.$ : neuro- $\left.2 \mathrm{~A}=23.8 \pm 4.2 \mu \mathrm{M}\right)$ to that previously reported for trichophycin $\mathrm{A}\left(\mathrm{EC}_{50}\right.$ : 
neuro- $2 \mathrm{~A}=6.5 \pm 1.4 \mu \mathrm{M})$ and to that of trichotoxin $\mathrm{A}\left(\mathrm{EC}_{50} \text { : neuro- } 2 \mathrm{~A} \geq 50 \mu \mathrm{M}\right)^{18}$ provides increasing evidence of an association of increasing cytotoxicity with increasing polyol character. However, the trichophycins displaying greater polyol character have longer carbon chains. Determining the cytotoxicity of dehydrated trichophycin analogs would provide greater insight into this relationship.

Predicted Biosynthesis. Trichophycins B-F (1-5) represent new analogs of trichophycin A and additions to the collection of structurally interesting halogenated cyanobacterial metabolites. The trichophycins recognizably derive from a standard PKS biosynthetic pathway(s). The most apparent structural differences among the trichophycins relate to the putative biosynthetic starter unit, the number of vinyl or alkynyl halide groups, and the mode of biosynthetic termination. While Trichodesmium theibautii was identified as the dominant species in the bloom from field characters, the bloom likely comprises multiple species of Trichodesmium. ${ }^{32}$ Thus, we cannot ascribe a single pathway to the origin of these metabolites. These metabolites may be generated by multiple pathways. This may explain the configuration differences at C-5 in $\mathbf{1}$ and C-4 in 2 . Potential flexibility in the loading module in the putative biosynthetic pathway of trichophycins $\mathrm{C}, \mathrm{D}$, and E (2-4) may confer the ability to incorporate a probable phenylacetate unit (1 and $\mathbf{2})$ and a 5-hexynoate unit (3 and 4). The 5-hexynoate unit is the proposed starter group in the biosynthesis of jamaicamide $\mathrm{A}^{13}$ and terminal alkynes are present in a number of cyanobacterial lipopeptides. ${ }^{33-}$ ${ }^{35}$ In jamaicamide A, the alkyne is proposed to arise from a 5-hexanoic acid precursor by the action of a fatty acid desaturase. ${ }^{13}$ Alkynyl bromide formation in jamaicamide $\mathrm{A}$ is proposed to occur through electrophilic addition by a haloperoxidase, ${ }^{36}$ which may also be the case with trichophycin E (4). The pendant vinyl group adjacent to the starter unit in the trichophycins would likely be generated by the action of an HMG-CoA synthase cassette, which has been shown to perform 
alkylation at the $\beta$ position in a growing polyketide chain. ${ }^{5,37}$ Subsequent chlorination would give rise to the chlorovinylidene. The terminal vinyl chloride present in $\mathbf{2 - 4}$ could arise from the action of an FAD-dependent halogenase as is proposed in the formation of a terminal vinyl bromide functionality in the macrocyclic polyketide phormidolide. ${ }^{38}$ The formation of the terminal alkene in 2-4 is likely similar to that of curacin A, in which a conserved tridomain of an ACP, sulfotransferase and decarboxylating thioesterase participate to form a terminal double bond resulting from sulfate elimination from the beta position and decarboxylation. ${ }^{39,40}$

Trichophycin F (5) adds to the biosynthetic questions surrounding this group of molecules as the biosynthesis of $\mathbf{5}$ may incorporate a glycine unit or 4-aminobutyric acid. Tricholactone $\mathbf{6}$ may be an oxidative degradation product of $\mathbf{5}$, and is the only molecule in the group isolated that does not feature at least one vinyl chloride group. The trichophycins and tricholactone were stored neat. While trichophycins B-F have remained stable, tricholactone degraded.

Without information on the gene cluster or clusters encoding the trichophycins, we are limited in our ability to understand the biosynthetic processes involved. Genomic studies are planned to address these questions surrounding biosynthesis.

\section{Experimental methods}

General Experimental Procedures. Optical rotations were measured using a Jasco P-2000 polarimeter. UV spectra were measured using a Beckman Coulter DU-800 spectrophotometer. CD spectra were recorded using a Jasco J-1100 CD spectrometer. NMR spectra were collected using Bruker 600 or $800 \mathrm{MHz}$ NMR instruments equipped with a cryoprobe and a Varian $500 \mathrm{MHz}$ instrument. HRESIMS analysis was performed using an AB SCIEX TripleTOF 4600 mass spectrometer with Analyst TF software. Semi-preparative HPLC was carried out using an Agilent 
1100 series HPLC or a Dionex UltiMate 3000 HPLC system each equipped with a micro vacuum degasser, an autosampler and a photodiode-array detector.

Collection of Biological Material. A localized bloom of Trichodesmium was collected from Padre Island, Corpus Christi, TX during 9-11 May 2014. Bloom material was collected from ca. 0.5-meter water depth by collecting surface bloom material in 5-gallon buckets. Approximately $300 \mathrm{~g}$ wet weight cell mass was concentrated from this material by gentle filtration through $18 \mu \mathrm{m}$ mesh. In the laboratory, a subsample of the cell mass was examined microscopically and identified according to Komarek (2005) $)^{41}$ by phycologist Paul V. Zimba at Texas A\&M Corpus Christi.

Extraction and Isolation of Compounds 1-6. Trichodesmium bloom material (14.4 g, dry wt) was repeatedly extracted with 2:1 $\mathrm{CH}_{2} \mathrm{Cl}_{2}-\mathrm{CH}_{3} \mathrm{OH}$ affording $3.95 \mathrm{~g}$ of crude lipophilic extract. The crude residue was reconstituted in hexanes and fractionated over silica gel using vacuum liquid chromatography (VLC) and a stepped gradient of hexanes, EtOAc and $\mathrm{CH}_{3} \mathrm{OH}$. The VLC fraction eluting with 40\% EtOAc in hexanes (Fraction D, $293.4 \mathrm{mg}$ ) was further fractionated over a $2 \mathrm{~g}$ Strata C18 SPE column eluting with 50\% $\mathrm{CH}_{3} \mathrm{CN}$ in $\mathrm{H}_{2} \mathrm{O}, 100 \% \mathrm{CH}_{3} \mathrm{CN}, 100 \% \mathrm{CH}_{3} \mathrm{OH}$ and $100 \%$ EtOAc. The fraction eluting with $100 \% \mathrm{CH}_{3} \mathrm{CN}(127.9 \mathrm{mg})$ was subjected to RP-HPLC using a YMC $5 \mu \mathrm{m}$ ODS column $(250 \times 10 \mathrm{~mm})$ with an elution solvent of $85 \% \mathrm{CH}_{3} \mathrm{CN}$ in $\mathrm{H}_{2} \mathrm{O}$ with $0.1 \%$ formic acid added. Trichophycin $\mathrm{D}(\mathbf{3})\left(1.0 \mathrm{mg}\right.$; $\left.\mathrm{t}_{\mathrm{R}} 3.75 \mathrm{~min}\right)$ was isolated along with a second impure HPLC fraction. This fraction was separated using a YMC $5 \mu \mathrm{m}$ ODS column $(250 \times 10$ mm) with an elution solvent of $80 \% \mathrm{CH}_{3} \mathrm{OH}$ in $\mathrm{H}_{2} \mathrm{O}$ with $0.1 \%$ formic acid added. Trichophycin $\mathrm{C}(2)$ (3.9 $\mathrm{mg}$; $\left.\mathrm{t}_{\mathrm{R}} 11.50 \mathrm{~min}\right)$ and trichophycin $\mathrm{E}(4)\left(0.1 \mathrm{mg}\right.$; $\left.\mathrm{t}_{\mathrm{R}} 12.50 \mathrm{~min}\right)$ were isolated from this fraction. The fractions eluting with 60\% EtOAc in hexanes and 80\% EtOAc in hexanes (Fractions E and F) were combined based on similarities in ${ }^{1} \mathrm{H}$ NMR signals (306.4 mg) and subjected to RPHPLC using a YMC $5 \mu \mathrm{m}$ ODS column $(250 \times 10 \mathrm{~mm})$ with an elution solvent of $80 \% \mathrm{CH}_{3} \mathrm{CN}$ in 
$\mathrm{H}_{2} \mathrm{O}$ with $0.1 \%$ formic acid added and trichophycin $\mathrm{B}(\mathbf{1})\left(17 \mathrm{mg} ; \mathrm{t}_{\mathrm{R}} 5.50 \mathrm{~min}\right)$ was isolated. The fractions eluting with $100 \%$ EtOAc and $25 \% \mathrm{CH}_{3} \mathrm{OH}$ in EtOAc in hexanes (Fractions $\mathrm{G}$ and $\mathrm{H}$ ) were combined based on similarities in ${ }^{1} \mathrm{H}$ NMR signals and similar LC-MS profiles and the combined material (390.9 mg) was fractionated over a $2 \mathrm{~g}$ Strata C18 SPE column following an identical fractionation pattern as that for fraction D. The fraction eluting with $100 \% \mathrm{CH}_{3} \mathrm{CN}(143.2$ mg) was subjected to RP-HPLC using a YMC $5 \mu \mathrm{m}$ ODS column $(250$ x $10 \mathrm{~mm})$ with an elution solvent of $70 \% \mathrm{CH}_{3} \mathrm{CN}$ in $\mathrm{H}_{2} \mathrm{O}$ with $0.1 \%$ formic acid and tricholactone $(6)\left(0.5 \mathrm{mg} ; \mathrm{t}_{\mathrm{R}} 16.00 \mathrm{~min}\right)$ was isolated along with a second impure fraction. A final purification of this impure material was carried out using a Kinetex $5 \mu \mathrm{m} \mathrm{C} 18$ column $(250 \times 10 \mathrm{~mm})$; mobile phase: $75 \% \mathrm{CH}_{3} \mathrm{CN}$ in water with $0.05 \%$ formic acid added to each solvent, flow $3 \mathrm{~mL} / \mathrm{min}$ and $2.0 \mathrm{mg}$ of 5 were isolated ( $\mathrm{t}_{\mathrm{R}}$, $9.0 \mathrm{~min})$.

\section{Trichophycin B (1):}

Pale yellow oil; $[\alpha]^{22}{ }_{\mathrm{D}}+10.0(c 0.20, \mathrm{MeOH}) ; \mathrm{UV}(\mathrm{MeOH}) \lambda_{\max }(\log \varepsilon) 211(4.1), 231(3.8) \mathrm{nm}$; ${ }^{1} \mathrm{H}$ NMR (800 MHz, $\mathrm{CDCl}_{3}$ ) and ${ }^{13} \mathrm{C} \mathrm{NMR}\left(200 \mathrm{MHz}, \mathrm{CDCl}_{3}\right.$ ), see Table 1; HRMS (ESI/QTOF) $m / z:[\mathrm{M}+\mathrm{H}]^{+}$(calcd for $\mathrm{C}_{24} \mathrm{H}_{34} \mathrm{ClO}_{4}, 421.2146$; found 421.2153).

\section{Trichophycin C (2):}

Colorless oil; $[\alpha]^{22}{ }_{\mathrm{D}}+26.8\left(c\right.$ 0.20, MeOH); UV $(\mathrm{MeOH}) \lambda_{\max }(\log \varepsilon) 204(4.0) \mathrm{nm} ;{ }^{1} \mathrm{H}$ NMR $\left(800 \mathrm{MHz}, \mathrm{CDCl}_{3}\right)$, see Table 2 and ${ }^{13} \mathrm{C} \mathrm{NMR}\left(200 \mathrm{MHz}, \mathrm{CDCl}_{3}\right)$, see Table 3; HRMS (ESI/QTOF) $m / z$ : $[\mathrm{M}+\mathrm{H}]^{+}$(calcd for $\mathrm{C}_{22} \mathrm{H}_{33} \mathrm{Cl}_{2} \mathrm{O}_{2}$, 399.1858; found 399.1853).

\section{Trichophycin D (3):}

Colorless oil; $[\alpha]^{22} \mathrm{D}+11.3(c 0.08, \mathrm{MeOH}) ; \mathrm{UV}(\mathrm{MeOH}) \lambda_{\max }(\log \varepsilon) 202(3.5) \mathrm{nm} ;{ }^{1} \mathrm{H}$ NMR $\left(800 \mathrm{MHz}, \mathrm{CDCl}_{3}\right)$, see Table 2 and ${ }^{13} \mathrm{C} \mathrm{NMR}\left(200 \mathrm{MHz}, \mathrm{CDCl}_{3}\right.$ ), see Table 3; HRMS (ESI/QTOF) $m / z$ : $[\mathrm{M}+\mathrm{H}]^{+}$(calcd for $\mathrm{C}_{20} \mathrm{H}_{33} \mathrm{Cl}_{2} \mathrm{O}_{2}, 375.1858$; found 375.1855).

\section{Trichophycin E (4):}

Colorless oil; UV (from UV scan during LC-MS analysis) $210 \mathrm{~nm} ;{ }^{1} \mathrm{H}$ NMR (800 MHz, $\mathrm{CDCl}_{3}$ ), see Table 2 and ${ }^{13} \mathrm{C}$ NMR (200 $\mathrm{MHz}, \mathrm{CDCl}_{3}$ ), see Table 3; HRMS (ESI/QTOF) $m / z:[\mathrm{M}+\mathrm{H}]^{+}$ (calcd for $\mathrm{C}_{20} \mathrm{H}_{32} \mathrm{BrCl}_{2} \mathrm{O}_{2}$, 453.0963; found 453.0961). 


\section{Trichophycin F (5):}

Colorless oil; $[\alpha]^{22} \mathrm{D}+17.4\left(c\right.$ 0.2, MeOH); UV (MeOH) $\lambda_{\max }(\log \varepsilon) 202(3.8), 229(3.5) \mathrm{nm} ;{ }^{1} \mathrm{H}$ NMR (800 MHz, CD 3 CN) and ${ }^{13} \mathrm{C}$ NMR (200 MHz, $\mathrm{CD}_{3} \mathrm{CN}$ ), see Table 4; HRMS (ESI/QTOF) $m / z:[\mathrm{M}+\mathrm{H}]^{+}$(calcd for $\mathrm{C}_{25} \mathrm{H}_{41} \mathrm{ClNO}_{4}, 454.2724$; found 454.2739).

\section{Tricholactone (6):}

Colorless oil; UV (from UV scan during LC-MS analysis) 210, $228 \mathrm{~nm} ;{ }^{1} \mathrm{H}$ NMR $(800 \mathrm{MHz}$, DMSO) and ${ }^{13} \mathrm{C}$ NMR (200 MHz, DMSO), see Table S2; HRMS (ESI/QTOF) $m / z:[\mathrm{M}+\mathrm{H}]^{+}$ (calcd for $\mathrm{C}_{14} \mathrm{H}_{23} \mathrm{O}_{4}, 255.1596$; found 255.1595).

Preparation and Analysis of MTPA esters. $1 \mathrm{mg}$ of trichophycin B (1) was dissolved in dry $\mathrm{CDCl}_{3}$ and separated into two equal portions in $4 \mathrm{~mL}$ vials. Dry pyridine $(10 \mu \mathrm{L})$ and $(S)-(+)-\alpha-$ methoxy- $\alpha$-(trifluoromethyl)phenylacetyl chloride $(15 \mu \mathrm{L})$ were added to the first vial. The vial was capped and the reaction mixture was stirred for $24 \mathrm{~h}$. The identical procedure was repeated with an equal amount of $\mathbf{1}$ and $(R)$-(-)-a-methoxy-a-(trifluoromethyl)phenylacetyl chloride. After $24 \mathrm{~h}$, the contents of the vials were immediately transferred to NMR tubes for further analysis. $\boldsymbol{S}$ ester ${ }^{1} \mathrm{H}$ NMR $\left(800 \mathrm{MHz}, \mathrm{CDCl}_{3}\right) \delta 7.28(2 \mathrm{H}, \mathrm{t}, J=7.4 \mathrm{~Hz}, \mathrm{H}-17, \mathrm{H}-19), 7.22(1 \mathrm{H}, \mathrm{d}, J=7.4 \mathrm{~Hz}$, H-18), 7.19 (2H, d, $J=7.4$ Hz, H-16, H-20), 5.89 (1H, s, H-21), $5.19(1 \mathrm{H}, \mathrm{s}, \mathrm{H}-2), 5.17(1 \mathrm{H}, \mathrm{m}$, H-11), $4.24(1 \mathrm{H}, \mathrm{dt}, J=13.0,3.7 \mathrm{~Hz}, \mathrm{H}-5), 3.73(3 \mathrm{H}, \mathrm{s}, \mathrm{H}-24), 3.72(1 \mathrm{H}, \mathrm{d}, J=14.8 \mathrm{~Hz}, \mathrm{H}-14 \mathrm{a})$, $3.46(1 \mathrm{H}, \mathrm{d}, J=14.8 \mathrm{~Hz}, \mathrm{H}-14 \mathrm{~b}), 2.57$ (1H, m, H-4a), 2.26 (1H, dd, $J=14.6,8.3 \mathrm{~Hz}, \mathrm{H}-12 \mathrm{a}), 2.17$ (1H, m, H-4b), 2.16 (1H, m, H-12b), 1.74 (1H, m, H-6), 1.63 (1H, m, H-8), 1.46, m, H-10a), 1.37 (1H, ovlp, H-7a), 1.36 (1H, ovlp, H-9a), 1.23 (1H, m, H-10b), 1.12 (1H, m, H-9b), 1.07 (1H, m, H-7b), 0.94 (3H, d, $J=6.8 \mathrm{~Hz}, \mathrm{H}-23), 0.81$ (3H, d, $J=6.6 \mathrm{~Hz}, \mathrm{H}-22)$; $\boldsymbol{R}$-ester ${ }^{1} \mathrm{H}$ NMR ( $800 \mathrm{MHz}$, $\left.\mathrm{CDCl}_{3}\right) \delta 7.28(2 \mathrm{H}, \mathrm{m}, \mathrm{H}-17, \mathrm{H}-19), 7.22(1 \mathrm{H}, \mathrm{m}, \mathrm{H}-18), 7.21(2 \mathrm{H}, \mathrm{d}, J=7.6 \mathrm{~Hz}, \mathrm{H}-16, \mathrm{H}-20)$, $5.97(1 \mathrm{H}, \mathrm{s}, \mathrm{H}-21), 5.19(1 \mathrm{H}, \mathrm{s}, \mathrm{H}-2), 5.17(1 \mathrm{H}, \mathrm{m}, \mathrm{H}-11), 4.24(1 \mathrm{H}, \mathrm{dt}, J=13.0,3.6 \mathrm{~Hz}, \mathrm{H}-5)$, $3.73(3 \mathrm{H}, \mathrm{s}, \mathrm{H}-24), 3.78(1 \mathrm{H}, \mathrm{d}, J=14.4 \mathrm{~Hz}, \mathrm{H}-14 \mathrm{a}), 3.47(1 \mathrm{H}, \mathrm{d}, J=18.0 \mathrm{~Hz}, \mathrm{H}-14 \mathrm{~b}), 2.71(1 \mathrm{H}$, dd, $J=17.0,12.8 \mathrm{~Hz}, \mathrm{H}-4 \mathrm{a}), 2.55(1 \mathrm{H}, \mathrm{dd}, J=17.0,3.5 \mathrm{~Hz}, \mathrm{H}-4 \mathrm{~b}), 2.32(1 \mathrm{H}, \mathrm{dd}, J=14.6,8.5 \mathrm{~Hz}$, 
H-12a), 2.20 (1H, dd, $J=14.4,4.5 \mathrm{~Hz}, \mathrm{H}-12 \mathrm{~b}), 1.74$ (1H, m, H-6), 1.53 (1H, m, H-8), 1.41 (1H, m, H-10a), 1.33 (1H, m, H-7a), 1.29 (1H, m, H-9a), 1.15 (1H, m, H-10b), 1.06 (1H, m, H-7b), 0.90 (1H, m, H-9b), 0.94 (3H, d, $J=6.8 \mathrm{~Hz}, \mathrm{H}-23), 0.77(3 \mathrm{H}, \mathrm{d}, J=6.6 \mathrm{~Hz}, \mathrm{H}-22)$.

The procedure above was performed on $1.8 \mathrm{mg}$ of trichophycin $\mathrm{C} \mathrm{(2).}$

Trichophycin C MTPA: $\boldsymbol{S}$-ester ${ }^{1} \mathrm{H}$ NMR $\left(500 \mathrm{MHz}, \mathrm{CDCl}_{3}\right) \delta 7.27(2 \mathrm{H}, \mathrm{t}, J=7.4 \mathrm{~Hz}, \mathrm{H}-16, \mathrm{H}-$ 18), $7.22(1 \mathrm{H}, \mathrm{d}, J=7.4 \mathrm{~Hz}, \mathrm{H}-17), 7.17$ (2H, d, $J=7.4 \mathrm{~Hz}, \mathrm{H}-15, \mathrm{H}-19), 5.89$ (1H, s, H-20), 5.87 $(1 \mathrm{H}, \mathrm{s}, \mathrm{H}-1), 5.68(1 \mathrm{H}, \mathrm{m}, \mathrm{H}-2), 5.16(1 \mathrm{H}, \mathrm{m}, \mathrm{H}-10), 4.99(1 \mathrm{H}, \mathrm{m}, \mathrm{H}-4), 3.70(1 \mathrm{H}, \mathrm{d}, J=14.5, \mathrm{H}-$ 13a), 3.49 (1H, m, H-13b), 2.25 (2H, m, H-3), 2.15 (2H, dd, J = 14.5, 4.5 Hz, H-11), 1.83 (1H, m, H-5), 1.55 (2H, m, H-9), 1.42 (1H, m, H-7), 1.19 (2H, ovlp, H-8), 1.18 (1H, ovlp, H-6a), 0.95 (1H, m, H-6b), $0.86(3 \mathrm{H}, \mathrm{d}, J=6.8 \mathrm{~Hz}, \mathrm{H}-21), 0.82(3 \mathrm{H}, \mathrm{d}, J=6.4 \mathrm{~Hz}, \mathrm{H}-22)$; $\boldsymbol{R}$-ester ${ }^{1} \mathrm{H}$ NMR $(500$ $\mathrm{MHz}_{\mathrm{CDCl}}$ ) $\delta 7.27$ (2H, m, H-16, H-18), $7.22(1 \mathrm{H}, \mathrm{m}, \mathrm{H}-17), 7.20(2 \mathrm{H}, \mathrm{d}, J=7.5 \mathrm{~Hz}, \mathrm{H}-15, \mathrm{H}-$ 19), 5.96 (1H, s, H-20), 5.99 (1H, s, H-1), 5.79 (1H, m, H-2), $5.16(1 \mathrm{H}, \mathrm{m}, \mathrm{H}-10), 4.97$ (1H, m, H4), 3.77 (1H, d, J = 14.5, H-13a), 3.49 (1H, m, H-13b), 2.31 (2H, m, H-3), 2.16 (2H, m, H-11), 1.78 (1H, m, H-5), 1.49 (2H, m, H-9), 1.31 (1H, m, H-7), 1.08 (2H, ovlp, H-8), 1.11 (1H, ovlp, H6a), 0.84 (1H, m, H-6b), 0.75 (3H, d, $J=6.7 \mathrm{~Hz}, \mathrm{H}-21), 0.73(3 \mathrm{H}, \mathrm{d}, J=6.8 \mathrm{~Hz}, \mathrm{H}-22)$.

Cytotoxicity Assay. Neuro-2A cells were added to assay plates in $100 \mu$ l of Eagle's Minimum Essential Media (EMEM) supplemented with 10\% FBS at a density of 5,000 cells/well. Cells were incubated overnight $\left(37^{\circ} \mathrm{C}, 5 \% \mathrm{CO}_{2}\right)$ and examined microscopically to confirm confluence and adherence. Test substances were dissolved in DMSO (1\% v/v) and added to the cells in the range of $100,10,1,0.1$ and $0.01 \mu \mathrm{M}$ in order to construct a dose response curve. Three technical replicates were prepared for each concentration and each assay was performed in triplicate. Doxorubicin was used as a positive control $\left(\mathrm{EC}_{50}: 0.112 \pm 0.021 \mu \mathrm{M}\right)$ and DMSO was used as a negative control. Plates were incubated for $72 \mathrm{~h}$ after which $15 \mu \mathrm{l}$ of MTT dye were added each 
assay well. The dye was allowed to incubate with the cells for $4 \mathrm{~h}$ after which media was aspirated and the remaining formazan crystals were solubilized in $100 \mu 1$ of DMSO. Absorbance at $540 \mathrm{~nm}$ was measured using a Molecular Devices SpectraMax plate reader and $\mathrm{EC}_{50}$ curves were generated and statistical procedures were performed using Graphpad Prism software.

\section{ASSOCIATED CONTENT}

\section{Supporting Information}

Tables of NMR spectroscopic data, DFT and $J$-coupling analysis, 1D and 2D NMR data, CD data, ${ }^{1} \mathrm{H}$ NMR of MTPA derivatives and dose-response curves for compounds 1-6 are available free of charge at http://pubs.acs.org.

\section{AUTHOR INFORMATION}

\section{Corresponding Author}

* (401) 874-5016; mbertin@uri.edu; Department of Biomedical and Pharmaceutical Sciences, College of Pharmacy URI, 7 Greenhouse Road, Kingston, RI 02881

\section{Author Contributions}

The manuscript was written through contributions of all authors. All authors have given approval to the final version of the manuscript.

\section{ACKNOWLEDGMENT}

We thank Paul V. Zimba and I-Shuo Huang at Texas A\&M Corpus Christi for field collection assistance and cyanobacteria identification. We thank Peter D. R. Moller of NOAA for assistance with NMR experiments. Research reported in this publication was made possible by the use of spectrometric and spectroscopic equipment and services available through the RI-INBRE 
Centralized Research Core Facility, which is supported by the Institutional Development Award (IDeA) Network for Biomedical Research Excellence from the National Institute of General Medical Sciences of the National Institutes of Health under grant number P20GM103430. Certain NMR experiments were conducted at a research facility at the University of Rhode Island supported in part by the National Science Foundation EPSCoR Cooperative Agreement \#EPS1004057. This work was supported in part by an American Society of Pharmacognosy Starter Grant awarded to M. Bertin.

\section{References}

(1) Gerwick W. H.; Moore, B. S. Lessons from the past and charting the future of marine natural products drug discovery and chemical biology. Chem. Biol. 2012, 19, 85-98.

(2) Nunnery, J. K.; Mevers, E.; Gerwick, W. G. Biologically active secondary metabolites from marine cyanobacteria. Curr. Opin. Biotechnol. 2010, 21, 787-793.

(3) Tan, L. T. Bioactive natural products from marine cyanobacteria for drug discovery. Phytochemistry 2007, 68, 954-979.

(4) Tan, L. T. Pharmaceutical agents from filamentous marine cyanobacteria. Drug. Discov. Today 2013, 18, 863-871.

(5) Kehr, J. C.; Picchi, D. G.; Dittmann, E. Natural product biosyntheses in cyanobacteria: a treasure trove of unique enzymes. Beilstein J. Org. Chem. 2011, 7, 1622-1635.

(6) Pereira, A. R.; Kale, A. J.; Fenley, A. T.; Byrum, T.; Debonsi, H. M.; Gilson, M. K.; Valeriote, F. A.; Moore, B. S.; Gerwick, W. H. The carmaphycins: new proteasome inhibitors exhibiting an $\alpha, \beta$-epoxyketone warhead form a marine cyanobacterium. Chembiochem. 2012, 13, 810-817. 
(7) Luesch, H.; Yoshida, W. Y.; Moore, R. E.; Paul, V. J.; Corbett, T. H. Total structure determination of apratoxin A, a potent novel cytotoxin from the marine cyanobacterium Lyngbya majuscula. J. Am. Chem. Soc. 2001, 123, 5418-5423.

(8) Aráoz, R.; Molgó, J.; Tandeau de Marsac, N. Neurotoxic cyanobacterial toxins. Toxicon. 2010, $56,813-828$.

(9) Berman, F. W.; Gerwick, W. H.; Murray, T. F. Antillatoxin and kalkitoxin, ichthyotoxins from the tropical cyanobacterium Lyngbya majuscula, induce distinct temporal patterns of NMDA receptor-mediated neurotoxicity. Toxicon. 1999, 37, 1645-1648.

(10) Vining, O. B.; Medina, R. A.; Mitchell, E. A.; Videau, P.; Li, D.; Serrill, D.; Kelly, J. X.; Gerwick, W. H.; Proteau, P. J.; Ishmael, J. E.; McPhail, K. L. Depsipeptide companeramides from a Panamanian marine cyanobacterium associated with the coibamide producer. J. Nat. Prod. 2015, $78,413-420$.

(11) Choi, H.; Mascuch, S. J.; Villa, F. A.; Byrum, T.; Teasdale, M. E.; Smith, J. E.; Preskitt, L. B.; Rowley, D. C.; Gerwick, L.; Gerwick, W. H. Honaucins A-C, potent inhibitors of inflammation and bacterial quorum sensing: synthetic derivatives and structure-activity relationships. Chem. Biol. 2012, 19, 589-598.

(12) Neumann, C. S.; Fujimori, D. G.; Walsh, C.T. Halogenation strategies in natural product biosynthesis. Chem. Biol. 2008, 15, 99-109.

(13) Edwards, D. J.; Marquez, B. L.; Nogle, L. M.; McPhail, K.; Goeger, D. E.; Roberts, M. A.; Gerwick, W. H. Structure and biosynthesis of the jamaicamides, new polyketide-peptide neurotoxins from the marine cyanobacterium Lyngbya majuscula. Chem. Biol. 2004, 11, 817-833. (14) Cardellina, J. H.; Marner, F. J.; Moore, R. E. Malyngamide A, a novel chlorinated metabolite of the marine cyanophyte Lyngbya majuscula. J. Am. Chem. Soc. 1979, 101, 240-242. 
(15) Gerwick, W. H.; Reyes, S.; Alvarado, B. Two malyngamides from the Caribbean cyanobacterium Lyngbya majuscula. Phytochemistry 1987, 26, 1701-1704.

(16) Nunnery, J. K.; Engene, N.; Byrum, T.; Cao, Z.; Jabba, S. V.; Pereira, A. R.; Teatulohi, M.; Murray, T. F.; Gerwick, W. H. Biosynthetically intriguing chlorinated lipophilic metabolites from geographically distant tropical marine cyanobacteria. J. Org. Chem. 2012, 77, 4198-4208.

(17) Schock, T. B.; Huncik, K.; Beauchesne, K. R.; Villareal, T. A.; Moeller, P. D. R. Identification of trichotoxin, a novel chlorinated compound associated with the bloom forming cyanobacterium, Trichodesmium thiebautii. Environ. Sci. Technol. 2011, 45, 7503, 7509.

(18) Bertin. M. J.; Wahome, P. G.; Zimba, P. V.; He, H.; Moeller, P. D. R. Trichophycin A, a cytotoxic linear polyketide isolated from a Trichodesmium thiebautii bloom. Mar. Drugs 2017, 15, 10.

(19) Teta, R.; Irollo, E.; Sala, G. D.; Pirozzi, G.; Mangoni, A.; Costantino, V. Smenamides A and B, chlorinated peptide/polyketide hybrids containing a dolapyrrolidinone unit from the Caribbean sponge Smenospongia aurea. Evaluation of their role as leads in antitumor drug research. Mar Drugs 2013, 11, 4451-4463.

(20) Wu, M.; Okino, T.; Nogle, L. M.; Marquez, B. L.; Williamson, R. T.; Sitachitta, N.; Berman, F. W.; Murray, T. F.; McGough, K.; Jacobs, R.; Colsen, K.; Asano, T.; Yokokawa, F.; Shioiri, T.; Gerwick, W. H. Structure, synthesis, and biological properties of kalkitoxin, a novel neurotoxin from the marine cyanobacterium Lyngbya majuscula. J. Am. Chem. Soc. 2000, 122, 12041-12042.

(21) Hoye, T. R.; Jeffrey, C. S.; Shao, F. Mosher ester analysis for the determination of absolute configuration of stereogenic (chiral) carbinol carbons. Nat. Protoc. 2007, 2, 2451-2458. 
(22) Snatzke, G. Circular dichroism and optical rotary dispersion - principles and application to the investigation of the stereochemistry of natural products. Angew. Chem. Int. Ed. 1968, 7, 1425.

(23) Beecham, A. F. The CD of $\alpha \beta$-unsaturated lactones. Tetrahedron 1972, 28, 5543-5554.

(24) Ellestad, G. A.; McGahren, W. J.; Kunstmann, M. P. Structure of a new fungal lactone, LLP880, from an unidentified Penicillium sp. J. Org. Chem. 1972, 37, 2045-2047.

(25) Tian, J. F.; Yu, R. J.; Li, X. X.; Gao, H.; Guo, L. D.; Tang, J. S.; Yao, X. S. ${ }^{1} \mathrm{H}$ and ${ }^{13} \mathrm{C}$ NMR spectral assignments of 2-pyrone derivatives from an endophytic fungus of sarcosoataceae. Magn. Reson. Chem. 2015, 53, 866-871.

(26) Sherer, E. C.; Lee, C. H.; Shpungin, J.; Cuff, J. F.; Da, C.; Ball, R.; Bach, R.; Crespo, A.; Gong, X.; Welch, C. J. Systematic approach to conformational sampling for assigning absolute configuration using vibrational circular dichroism. J. Med. Chem. 2014, 57, 477-494.

(27) Deng, W.; Cheeseman, J. R.; Frisch, M. J. Calculation of nuclear spin-spin coupling constants of molecules with first and second row atoms in study of basis set dependence. J. Chem. Theory and Comput. 2006, 2, 1028-1037.

(28) Sinnaeve, D.; Foroozandeh, M.; Nilsson, M.; Morris, G. A. A general method for extracting individual coupling constants from crowded (1)H NMR spectra. Angew. Chem. Int. Ed. Engl. 2016, 55, 1090-1093.

(29) Nolis, P.; Espinosa, J. F.; Parella, T. Optimum spin-state selection for all multiplicities in the acquisition dimension of the HSQC experiment. J. Magn. Reson. 2006, 180, 39-50.

(30) Gil, S.; Espinosa, J. F.; Parella, T. Accurate measurement of small heteronuclear coupling constants from pure-phase $\alpha / \beta$ HSQMBC cross-peaks. J. Magn. Reson. 2011, 213, 145-150. 
(31) Saurí, J.; Parella, T. On the interference of J(HH) modulation in HSQMBC-IPAP and HMBCIPAP experiments. Magn. Reson. Chem. 2013, 51, 509-516.

(32) Hynes, A. M.; Webb, E. A.; Doney, S. C.; Waterbury. Comparison of cultured Trichodesmium (Cyanophyceae) with species characterized from the field. J. Phycol. 2012, 48, 196-210.

(33) Mevers, E.; Liu, W. T.; Engene, N.; Mohimani, H.; Byrum, T.; Pevzner, P. A.; Dorrestein, P. C.; Spadafora, C.; Gerwick, W. H. Cytotoxic veraguamides, alkynyl bromide-containing cyclic depsipeptides from the marine cyanobacterium cf. Oscillatoria margaritifera. J. Nat. Prod. 2011, 74, 928-936.

(34) Jiménez, J. I.; Scheuer, P. J. New lipopeptides from the Caribbean cyanobacterium Lyngbya majuscula. J. Nat. Prod. 2001, 64, 200-203.

(35) Hooper, G. J.; Orjala, J.; Schatzman, R. C.; Gerwick, W. H. Carmabins A and B, new lipopeptides from the Caribbean cyanobacterium Lyngbya majuscula. J. Nat. Prod. 1998. 61, 529533.

(36) Boudreau, P. D.; Monroe, E. A.; Mehrotra, S.; Desfor, S.; Korobeynikov, A.; Sherman, D. H.; Murrary, T. F.; Gerwick, L.; Dorrestein, P. C.; Gerwick, W. H. Expanding the described metabolome of the marine cyanobacterium Moorea producens JHB through orthogonal natural products workflows. PLoS One. 2015, 10, e0133297.

(37) Buchholz, T. J.; Rath, C. M.; Lopanik, N. B.; Gardner, N. P; Håkansson, K.; Sherman, D. H. Polyketide $\beta$-branching in bryostatin biosynthesis: identification of surrogate acetyl-ACP donors for BryR, and HMG-ACP synthase. Chem. Biol. 2010, 17, 1092-1100.

(38) Bertin, M. J.; Vulpanovici, A.; Monroe, E. A.; Korobeynikov, A.; Sherman, D. H.; Gerwick, L.; Gerwick, W. H. The phormidolide biosynthetic gene cluster: a trans-AT PKS pathway encoding a toxic macrocyclic polyketide. ChemBioChem. 2016, 17, 164-173. 
(39) Chang, Z.; Sitachitta, N.; Rossi, J. V.; Roberts, M. A.; Flatt, P. M.; Jia, J.; Sherman, D. H.; Gerwick, W. H. Biosynthetic pathway and gene cluster analysis of curacin A, an antitubulin natural product from the tropical marine cyanobacterium Lyngbya majuscula. J. Nat. Prod. 2004, 67, 1356-1367.

(40) Gehret, J. J.; Gu, L.; Gerwick, W. H.; Wipf, P.; Sherman, D. H.; Smith, J. L. Terminal alkene formation by the thioesterase of curacin A biosynthesis: structure of a decarboxylating thioesterase. J. Biol. Chem. 2011, 286, 14445-14454.

(41) Komárek, J.; Anagnostidis, K. Cyanoprokarota Part 2: Oscillatoriales; Elsevier: München, Germany, 2005; pp. 1- 759 . 